\title{
SOLARIZAÇÃO DO SOLO ASSOCIADA À INCORPORAÇÃO DE MATÉRIAS ORGÂNICAS PARA O CONTROLE DE Pythium spp.
}

\section{IVONE ALBERTA SWART SCHOENMAKER}

\author{
Bióloga
}

\section{Orientadora: Dra. RAQUEL GHINI}

\begin{abstract}
Dissertação apresentada `a Escola Superior de Agricultura "Luiz de Queiroz", Universidade de São Paulo, para obtenção do título de Mestre em Agronomia, Área de Concentração: Fitopatologia.
\end{abstract}

PIRACICABA

Estado de São Paulo - Brasil

Março - 2001 
Dados Internacionais de Catalogação na Publicação (CIP) DIVISÃO DE BIBLIOTECA E DOCUMENTAÇÃO - Campus "Luiz de Oueiroz"/USP

Schoenmaker, Ivone Alberta Swart

Solarização do solo associada à incorporação de matérias orgânicas para o controle de Pythium spp. / Ivone Alberta Swart Schoenmaker. - Piracicaba, 2001.

$50 \mathrm{p}$.

Dissertação (mestrado) - - Escola Superior de Agricultura Luiz de Queiroz, 2001. Bibliografia.

1. Crisântemo 2. Fungo fitopatogênico 3. Matéria orgânica 4. Microbiologia do solo 5. Pepino 6. Propriedade fisico-química do solo 7. Solarização do solo I. Título

CDD 631.46 
Ao meu marido Klaas, por todo carinho, apoio e compreenção

\section{DEDICO}




\section{AGRADECIMENTOS}

À Dra. Raquel Ghini, pela orientação, paciência, amizade e todos ensinamentos durante este período de minha vida.

Aos meus pais, Piet e Bets e irmãos pelo total apoio, sempre.

Ao meu filho Pieter que esteve junto durante parte do mestrado.

Aos colaboradores da Fazenda "Terra Viva", especialmente Ricardo Alves, por tornar parte do trabalho viável.

Um especial agradecimento aos colaboradores da Embrapa Meio Ambiente, Mara, Rosângela, Abraão, Valdemori e a todos que muito contribuíram.

À Dra. Carmen Pires Zottarelli, pesquisadora do Instituto de Botânica de São Paulo, pela colaboração na identificação dos isolados do patógeno.

Ao Prof. Dr. Carlos Tadeu dos Santos Dias pela colaboração nas análises estatísticas.

Aos professores do Departamento de Fitopatologia pelos seus ensinamentos e aos colegas, especialmente Nilceli, Andrea, Rosângela e Cláudia pela ótima convivência.

E a todos que contribuíram para a realização deste trabalho, sobre tudo a Deus que me acompanhou em cada viagem a Piracicaba e por ter colocado pessoas valiosas no meu caminho. 


\section{SUMÁRIO}

Página

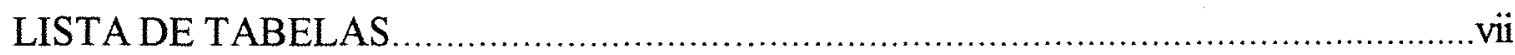

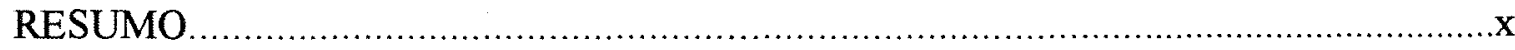

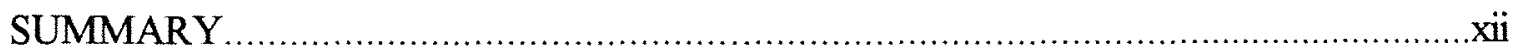

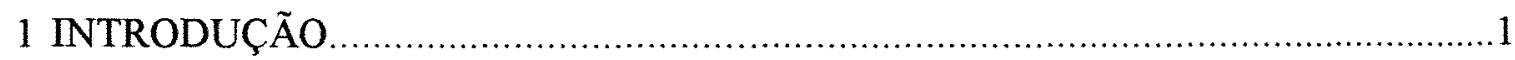

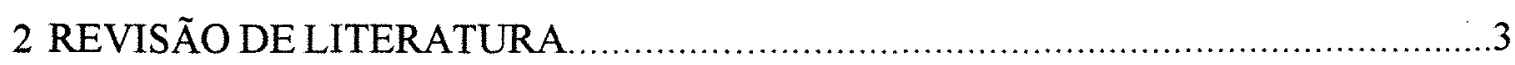

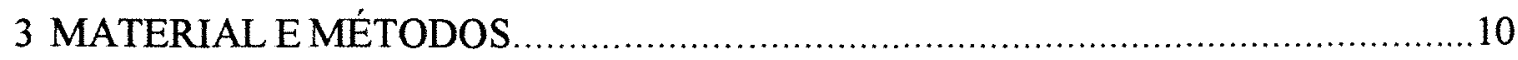

3.1 Ensaios em casa de vegetação..............................................................

3.1.1 Efeito de fontes de matéria orgânica no crescimento micelial de Pythium sp. e

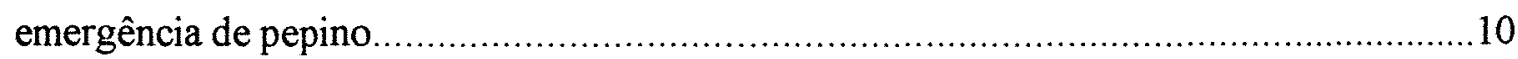

3.1.2 Controle do tombamento de pepino, causado por Pythium spp., com a utilização de diferentes fontes de matéria orgânica......................................................11

3.1.3 Comparação entre diferentes camas-de-frango........................................ 12

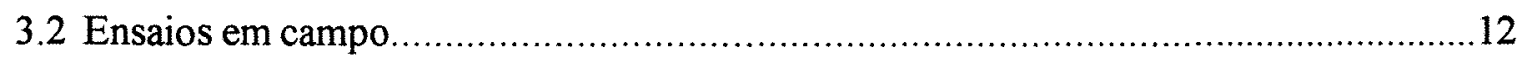

3.2.1 Solarização do solo associada a matérias orgânicas para o controle de Pythium sp.

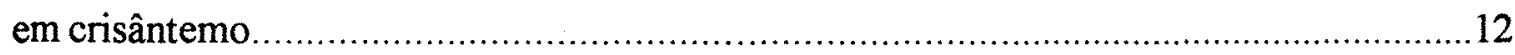

3.2.1.1 Incorporação de matérias orgânicas e solarização ..................................13

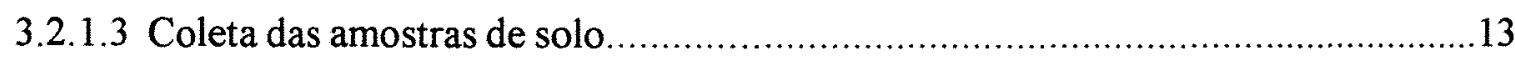

3.2.1.4 Umidade do solo......................................................................... 14

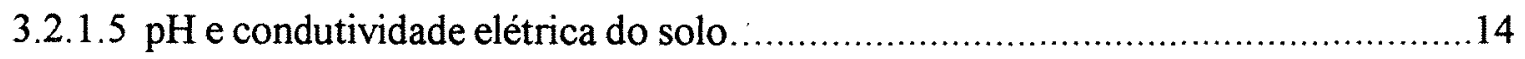

3.2.1.6 Atividade microbiana do solo............................................................ 14

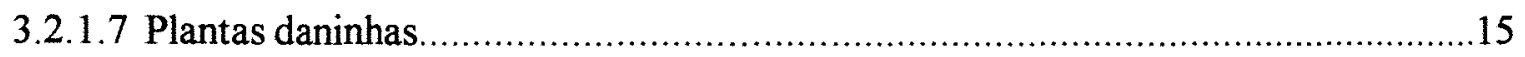

3.2.1.8 Resistência do solo à penetração............................................................ 15

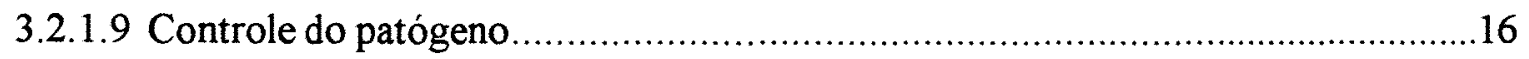

3.2.1.10 Altura de plantas de crisântemo e peso do sistema radicular.........................16

3.2.2 Solarização do solo associada a matérias orgânicas para o controle de Pythium

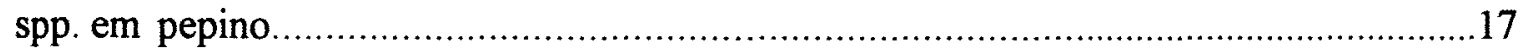

3.3 Identificação de espécies de Pythium ..................................................... 18 
4 RESULTADOS E DISCUSSÃO

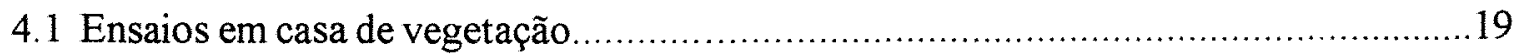

4.1.1 Efeito de fontes de matéria orgânica no crescimento micelial de Pythium sp. e

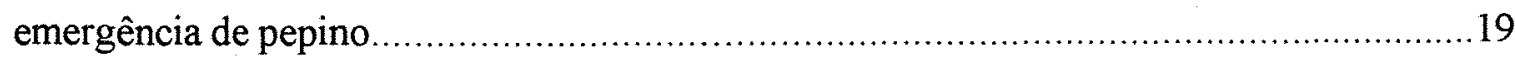

4.1.2 Controle do tombamento de pepino, causado por Pythium spp., com a utilização de

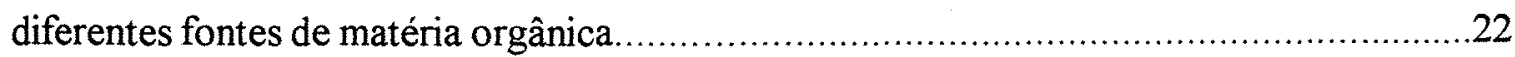

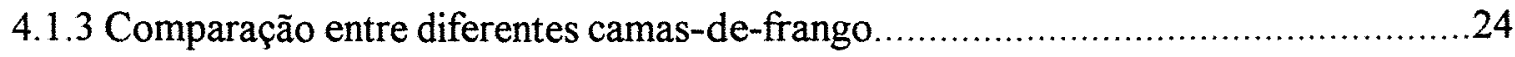

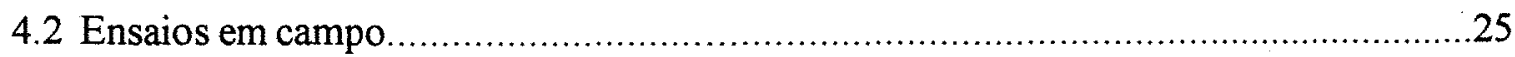

4.2.1 Solarização do solo associada a matérias orgânicas para o controle de Pythium sp.

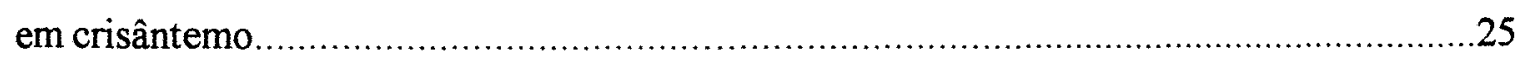

4.2.1.1 Análises químicas do solo e das matérias orgânicas. .....................................25

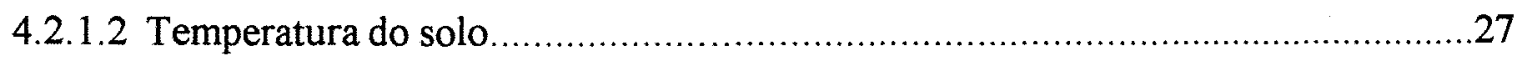

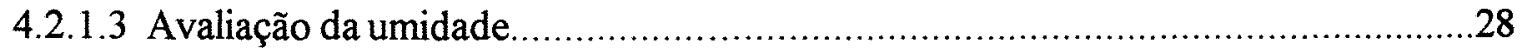

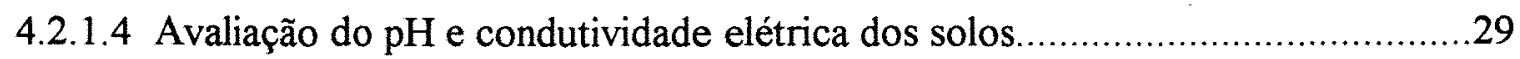

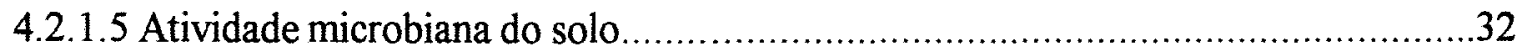

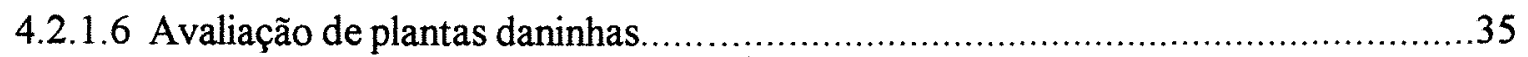

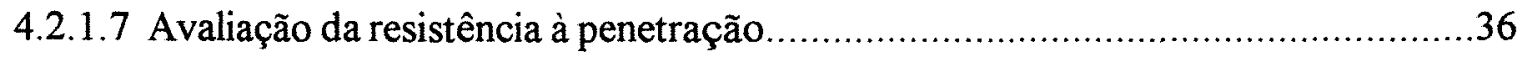

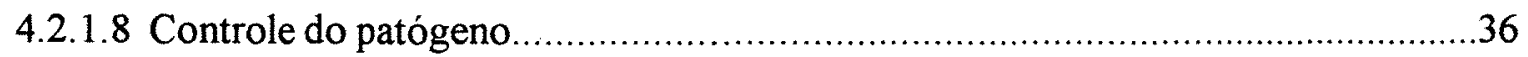

4.2.1.9 Altura de plantas de crisântemo e peso do sistema radicular..............................38

4.2.2 Solarização do solo associada a matérias orgânicas para o controle de Pythium spp

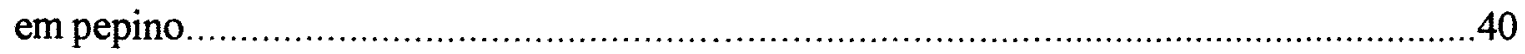

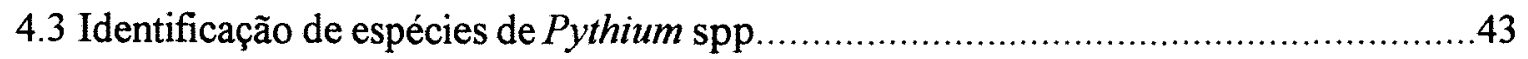

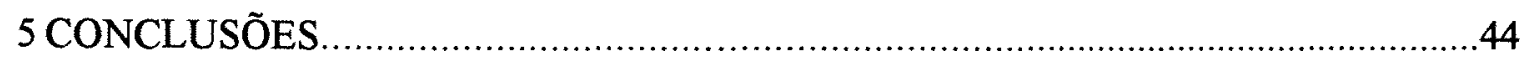

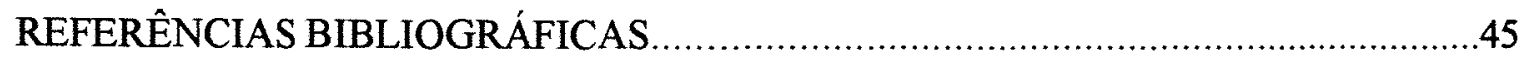




\section{LISTA DE TABELAS}

Página

1 Efeito de fontes de matéria orgânica no crescimento micelial de Pythium sp..........20

2 Efeito de fontes de matéria orgânica na emergência de plântulas de pepino............21

3 Efeito de fontes de matéria orgânica no tombamento de plântulas de pepino,

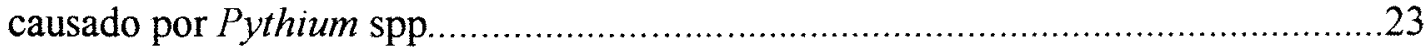

4 Comparação entre camas-de-frango obtidas de diferentes sistemas de produção quanto ao tombamento causado por Pythium spp. e a emergência de plântulas de pepino

5 Análise química do solo do campo utilizado para a realização do ensaio de solarização do solo associada a matérias orgânicas para o controle de Pythium spp. em crisântemo. 26

6 Análise química das matérias orgânicas utilizadas no ensaio de solarização do solo associada a matérias orgânicas para $o$ controle de Pythium spp. em crisântemo.

7 Número de horas em que as temperaturas do solo superaram 36,38 e $40^{\circ} \mathrm{C}$, durante a primeira quinzena de solarização (de 12 a 24 fevereiro) e a segunda quinzena ( 3 a 17 de março de 1999) de solarização, na profundidade de 10 $\mathrm{cm}$. 28

8 Umidade (\%) dos solos dos diferentes tratamentos, 15, 35, 91 e 138 dias após a incorporação da matéria orgânica. .29

9 pH dos solos em diferentes períodos de avaliação durante ensaio de solarização do solo associada a matérias orgânicas para o controle de Pythium spp. em crisântemo. 30

10 Condutividade elétrica $\left(\mathrm{mS} . \mathrm{cm}^{-1}\right)$ dos solos em diferentes periodos de avaliação durante ensaio de solarização do solo associada a matérias orgânicas para o controle de Pythium spp. em crisântemo

11 Atividade microbiana do solo, avaliada pela hidrólise de diacetato de fluoresceina ( $\mu \mathrm{g}$ FDA hidrolisado/g solo seco), em diferentes períodos de avaliação durante 
ensaio de solarização do solo associada a matérias orgânicas para o controle de Pythium spp. em crisântemo.

12 Atividade microbiana do solo, avaliada pelo desprendimento de $\mathrm{CO}_{2}\left(\mathrm{mg} \mathrm{CO}_{2} / \mathrm{g}\right.$ solo seco), em diferentes períodos de avaliação durante ensaio de solarização do solo associada a matérias orgânicas para $o$ controle de Pythium spp. em crisântemo. 34

13 Efeito de fontes de matéria orgânica e da solarização no peso de matéria fresca e seca de plantas daninhas $\left(\mathrm{g} / \mathrm{m}^{2}\right)$

14 Efeito de fontes de matéria orgânica e da solarização na resistência a penetração no solo $\left(\mathrm{kgf} / \mathrm{cm}^{2}\right)$ 36

15 Efeito de fontes de matéria orgânica e da solarização na sobrevivência de Pythium spp. avaliada pelo tombamento de mudas de pepino (\%) em diferentes períodos de avaliação.

16 Correlação linear simples entre as variáveis avaliadas no ensaio de solarização associada a matérias orgânicas para o controle de Pythium spp. em crisântemo, aos 15 dias após a incorporação das matérias orgânicas ao solo.

17 Efeito de fontes de matéria orgânica e da solarização na altura de plantas de crisântemo $(\mathrm{cm})$.

18 Efeito de fontes de matéria orgânica e da solarização no peso de raízes de plantas de crisântemo (g/planta)

19 Efeito de fontes de matéria orgânica e da solarização na umidade do solo, após término da solarização, no ensaio de solarização do solo associada a matérias orgânicas para o controle de Pythium spp. em pepino.

20 Atividade microbiana do solo, avaliada pela hidrólise de diacetato de fluoresceina ( $\mu \mathrm{g}$ FDA hidrolisado/g solo seco) durante ensaio de solarização do solo associada a matérias orgânicas para o controle de Pythium spp. em pepino. 
21 Atividade microbiana do solo, avaliada pelo desprendimento de $\mathrm{CO}_{2}(\mathrm{mg} \mathrm{CO} / \mathrm{g}$ solo seco), durante ensaio de solarização do solo associada a matérias orgânicas para o controle de Pythium spp. em pepino.

22 Efeito de fontes de matéria orgânica e da solarização do solo na porcentagem de plantas de pepino sadias em solo infestado com Pythium spp.

23 Efeito de fontes de matéria orgânica e da solarização na recuperação de Pythium spp. com utilização de iscas feitas com cubos de batata. 


\title{
SOLARIZAÇÃO DO SOLO ASSOCIADA À INCORPORAÇÃO DE MATÉRIAS ORGÂNICAS PARA O CONTROLE DE Pythium spp.
}

\author{
Autora: IVONE ALBERTA SWART SCHOENMAKER \\ Orientadora: Dra. RAQUEL GHINI
}

\section{RESUMO}

Inicialmente, em ensaios conduzidos em casa de vegetação, as seguintes matérias orgânicas foram testadas quanto ao controle de Pythium spp.: biossólido oriundo da ETE de Franca/SP; cama-de-frango; casca de Pinus; composto produzido com resíduos de flores com três semanas, três meses e seis meses de decomposição; folhas de repolho e de couve-flor. Somente as folhas de couve-flor (20\%) promoveram a inibição do crescimento micelial do patógeno. Folhas de couve-flor, biossólido e cama-de-frango apresentaram controle do tombamento de plântulas de pepino. A casca de Pinus e os compostos produzidos com resíduos de flores não apresentaram controle da doença. Camas-de-frango provenientes de três granjas (duas convencionais e uma do sistema orgânico) controlaram o patógeno de forma semelhante, indicando que os tratamentos químicos usados na produção de frangos não são os responsáveis pelo controle do patógeno.

Em ensaios conduzidos em campo, a solarização do solo associada à incorporação de biossólidos, cama-de-frango e casca de Pinus foi testada para o controle da doença em crisântemo e pepino. A adição de cama-de-frango induziu supressividade ao patógeno visto que resultou em maiores temperaturas no solo solarizado, aumento na condutividade elétrica, maior atividade microbiana (avaliada pela hidrólise de diacetato de fluoresceina e desprendimento de $\mathrm{CO}_{2}$ ) e menor resistência à penetração no solo. $\mathrm{A}$ 
solarização controlou as plantas daninhas, não teve efeito no crescimento de plantas de crisântemo e peso de raizes. A solarização não teve efeito significativo no controle do patógeno no ensaio conduzido com crisântemo, mas teve no ensaio realizado com pepino.

Há uma diversidade de espécie de Pythium nos solos estudados, sendo obtidos isolados de $P$. ultimum var. ultimum, $P$. aphanidermatum e $P$. graminicola. 


\title{
SOIL SOLARIZATION ASSOCIATED WITH THE AMENDMENT OF ORGANIC MATTERS FOR THE CONTROL OF Pythium SPP.
}

\author{
Author: IVONE ALBERTA SWART SCHOENMAKER
}

Adviser: Dr. RAQUEL GHINI

\section{SUMMARY}

Under green house conditions, the following organic matters were tested for control of Pythium spp.: biossolid from ETE of Franca/SP; chicken litter; Pinus bark; three-week-, three-month-, and six-month-composted flower residues; leaves of cabbage and cauliflower. Only cauliflower leaves $(20 \%)$ caused inhibition of micelial growth of the pathogen. Cauliflower, biossolid and chicken litter controled cucumber damppingoff, while Pinus bark and flower residues had no effect. Chicken litters originated from three producers, two conventionals and another from organic system, controlled the pathogen at the same level, indicating that chemicals applied on chickens are not responsible for Pythium spp. control.

Under field conditions, solarized soil amended with biossolid, chicken litter and Pinus bark were tested for the control of the disease on chrysanthemum and cucumber crops. The chicken litter amendment suppressed the pathogen due to higher temperatures during solarization, enhancement of electrical condutivity, and microbial activity (evaluated by diacetate fluorescein hidrolysis and $\mathrm{CO}_{2}$ emission methods), and lower resistance to soil penetration. Solarization controled weeds, but did not affect plant growth and root weight. Solarization controlled the pathogen in cucumber but not in chrysanthemum.

There was a diversity of Pythium species in the soils studied, which were colonized at least by $P$. ultimum var. ultimum, $P$. aphanidermatum and $P$. graminicola. 


\section{INTRODUÇÃO}

Pythium spp. ocorrem em praticamente todos os solos, atacando um grande número de culturas. Em crisântemo, por exemplo, as hastes se tornam escuras e colapsam rapidamente, causando murchamento da planta; nas folhas, onde o fungo pode invadir por meio do contato com o solo, surgem lesões escuras; e as raízes se tornam menos desenvolvidas devido ao apodrecimento causado pelo fungo (Horst \& Nelson, 1997). A disseminação ocorre pela água de irrigação, além de substratos, mudas e instrumentos contaminados utilizados no cultivo (Imenes \& Alexandre, 1996).

O controle preventivo é o mais recomendado, evitando-se a entrada do patógeno na área, haja vista que uma vez introduzidos no solo, tanto a convivência quanto a erradicação desse patógeno apresentam problemas, devido aos poucos métodos de controle disponíveis e suas desvantagens. Algumas cultivares são mais tolerantes ao patógeno, porém, sob condições ambiente favoráveis à ocorrência da doença, podem ocorrer perdas significativas. O principal método físico utilizado é a aplicação de vapor produzido por caldeiras, entretanto o custo do tratamento o torna viável somente para cultivo em estufas. Condições de estresse para as plantas podem aumentar a incidência da doença, tais como excesso de água, sais solúveis no solo e pH inadequado (Armitage, 1994).

O tratamento de solo com produtos químicos envolve o uso de fumigantes, como brometo de metila. O produto é altamente tóxico, sendo empregado como inseticida, fungicida, nematicida e herbicida, exigindo cuidados quanto à segurança do aplicador. Recentemente, descobriu-se que o brometo também possui ação destruidora da camada de ozônio da estratosfera terrestre, o que levará ao cancelamento do seu registro dentro de poucos anos (Reunião Brasileira sobre alternativas ao brometo de metila, 1997). 
Além disso, a desinfestação com o brometo promove a formação de vácuos biológicos, já que o produto é um biocida. Assim sendo, há maior facilidade de reinfestação do solo tratado, devido à eliminação da microbiota. Outros fungicidas específicos também são utilizados, como metalaxyl e propamocarb, na forma de regas do solo (Kimati et al., 1997).

Face aos problemas no controle de diversos fitopatógenos habitantes do solo em diferentes culturas, alguns métodos alternativos foram desenvolvidos com a finalidade de obter um controle mais eficiente e seguro, tanto para o aplicador como para o ambiente. Um dos métodos é a solarização que foi desenvolvida por Katan et al. (1976) e vem sendo utilizada em diversos países. Consiste na cobertura do solo com um filme plástico transparente antes do plantio, em solo preferencialmente úmido, durante o periodo de maior radiação solar. O aquecimento das camadas de solo induz processos microbianos que promovem o controle de fitopatógenos, de forma a alterar a microbiota em favor de antagonistas, tornando o solo mais supressivo (Katan \& DeVay, 1991). A associação de matéria orgânica à solarização pode resultar num controle mais efetivo, devido ao aumento da atividade e da população microbiana no solo (Ramirez-Villapudua \& Munnecke, 1988). A adição de matéria orgânica também melhora as características físicas e químicas do solo, influenciando a microbiota.

Dentre as fontes disponíveis de matéria orgânica, os biossólidos constituem uma rica fonte de macro e micronutrientes, aumentando a produtividade de diversos solos agrícolas (Lewis et al., 1992). O crescente volume de biossólidos disponíveis nas usinas de tratamento de lodo de esgoto torna necessária a busca de uma utilização viável para esse material. Para o uso na agricultura, são necessários testes para se determinar os seus efeitos no agroecossistema, especialmente quanto às características físico-químicas do solo e controle de fitopatógenos.

Dessa forma, o presente trabalho tem como objetivo avaliar a solarização associada à incorporação de fontes de matéria orgânica, com diferentes relações $\mathrm{C} N$, no controle de Pythium spp. em crisântemo e pepino e seus efeitos em algumas características físicas, químicas e microbiológicas do solo. 


\section{REVISÃO DE LITERATURA}

Entre os patógenos veiculados pelo solo, Pythium spp. estão entre os mais freqüentes, especialmente em cultivos intensivos. Em crisântemo, por exemplo, dentre os problemas fitossanitários da cultura, a podridão de raízes ocasionada por espécies de Pythium pode constituir-se num sério problema durante o verão (Cox, 1969). Várias espécies de Pythium já foram relatadas em diversos países, como agentes causais dessa doença. No Brasil, Silva et al. (1989) identificaram espécies de Pythium associadas à podridão de raízes de crisântemo "Polaris" e avaliaram a reação das cultivares "Crespo Branco" e "Macarrão Branco" aos isolados de Pythium spp. Obtiveram dois isolados pertencentes ao gênero Pythium: $P$. mamillatum e complexo $P$. rostratum e verificaram que as três cultivares eram suscetiveis às duas espécies de Pythium inoculadas, apresentando redução na altura e no peso seco das plantas, menor desenvolvimento radicular e incidência de podridão de raízes.

A aplicação de brometo de metila é um dos tratamentos químicos mais utilizados para a desinfestação do solo. Porém, como esse produto consiste em um dos gases responsáveis pela destruição da camada de ozônio da Terra, o protocolo de Montreal, assinado em 1987 por mais de 150 países, determina medidas para a redução de seu consumo e eliminação do mercado (Reunião brasileira sobre alternativas ao brometo de metila, 1997).

A solarização é um método alternativo de desinfestação do solo para o controle de fitopatógenos, plantas daninhas e pragas, desenvolvida por Katan et al. (1976). A cobertura com um filme plástico promove a elevação da temperatura do solo pela energia solar e quanto maior a profundidade, menores são as temperaturas atingidas, de modo que é necessário um tempo maior de exposição para que ocorra a inativação das 
estruturas do patógeno. Parte da população dos patógenos morre por efeito direto da elevação da temperatura, especialmente as estruturas localizadas na superfície e nas camadas mais profundas, onde são obtidas temperaturas subletais. Além da exposição à temperatura, os processos microbianos induzidos pela solarização também contribuem para o controle das doenças, pois o aquecimento atua sobre a microbiota do solo em geral e esses processos microbianos são importantes em profundidades onde as temperaturas são subletais ou em climas cujas temperaturas não são favoráveis à solarização (Ghini, 1997). Diversos trabalhos realizados comprovaram que temperatura de $65^{\circ} \mathrm{C}$ durante 30 minutos é letal para a maioria dos patógenos de plantas, mas pouco se sabe sobre o tempo de exposição necessário para matar patógenos de solo a temperaturas inferiores de $45^{\circ} \mathrm{C}$. Pullman et al. (1981) verificaram que temperaturas sub-letais causam atraso na germinação, o que varia conforme a temperatura e o tempo de exposição, indicando que danos causados pelo calor se acumulam gradualmente até se chegar ao ponto que o propágulo não mais se recupera e que provavelmente temperaturas letais diminuem a habilidade do patógeno em suportar futuras situações de estresse e causar doença em plantas. Bihan et al. (1997) verificaram que a solarização promove um controle apropriado de Pythium spp. agente causal de damping-off em viveiros de florestais na França, mas observaram a sobrevivência do patógeno nas camadas mais profundas. Mansoori \& Jaliani (1996) observaram no Iran redução de 12, 17 e $10 \%$ de incidência de doenças em melancia causados por patógenos de solo após períodos de 30, 45 e 60 dias de solarização. Bettiol et al. (1994) testaram a solarização e obtiveram o controle de Pythium sp. e de plantas daninhas na cultura de crisântemo. Patricio (2000) verificou que Pythium aphanidermatum não foi consistentemente controlado pela solarização em ambiente protegido ou não, sendo que em alguns experimentos ocorreu redução na viabilidade do patógeno nas camadas mais superficiais do solo, sendo que foi acompanhada pelo favorecimento de sua patogenicidade na profundidade de $20 \mathrm{~cm}$.

O efeito do aquecimento artificial (vapor) é muito mais drástico nos componentes bióticos do solo pois as altas temperaturas atingidas levam a formação do chamado "vácuo biológico", constituído por espaços estéreis e a redução da população de 
antagonistas geralmente significa uma rápida disseminação do patógeno reintroduzido. Dessa forma, na solarização as temperaturas atingidas permitem a sobrevivência de alguns grupos de microrganismos, entre eles muitos antagonistas que são mais tolerantes ao calor e competitivos do que os patógenos de plantas. Ocorre então uma alteração na composição microbiana em favor de antagonistas, estimulando a supressividade do solo a patógenos, dificultando a reinfestação e permitindo que o tratamento dure diversos ciclos da cultura (Ghini, 1997). Segundo Katan \& DeVay (1991), o efeito da solarização se prolonga por mais de um ciclo de plantio, o que demonstra vantagem sobre o uso de fungicidas e herbicidas que é realizado antes de todo plantio.

Em muitos casos, a solarização pode ser beneficiada através da integração desse tratamento com outros métodos de desinfestação, por exemplo, métodos químicos e biológicos. A combinação da solarização com a incorporação de matérias orgânicas para obter a biofumigação tem demonstrado resultados na desinfestação de campos ou mesmo no preparo de substratos (Stapleton \& DeVay, 1995).

A utilização de matérias orgânicas exerce um efeito positivo melhorando as características fisico-químicas do solo e também pode ter efeito no controle de doenças de plantas. Resultados de trabalhos com o uso de compostos orgânicos no controle de doenças das plantas têm mostrado que os níveis de controle variam em função do patossistema e do tipo de composto orgânico empregado, tais como: origem do material a ser compostado, o método de compostagem, o estágio de maturação do composto, a composição populacional dos microrganismos decompositores do material orgânico, etc. Um composto orgânico quando incorporado ao solo pode torná-lo supressivo ou conducente em função da relação $\mathrm{C} / \mathrm{N}$ e da habilidade competidora do fitopatógeno (Vida et al., 1998).

A atividade microbiana de alguns solos pode prevenir o estabelecimento de fitopatógenos ou inibir suas atividades patogênicas. A expressão comumente usada na literatura é "solo supressivo" e o oposto é denominado "conducente". A denominação "solo supressivo a patógenos" não necessariamente significa a eliminação do patógeno do solo, mas a ausência ou a supressão da doença nos casos em que plantas suscetíveis são cultivadas nesse solo (Reis, 1991). A supressão do desenvolvimento de doenças 
pode ocorrer através da fungistase; pouca habilidade competitiva saprofitica do patógeno; antibiose; ou outra forma de controle biológico ou químico ainda não esclarecido. Solos em estufas são freqüentemente esterilizados não apresentando fatores biológicos que podem torná-los supressivos, mas a adição de organismos apropriados podem torná-los supressivos. A adição de diversos compostos como: turfa, adubo verde e compostos pode manter populações mistas de organismos antagonistas (Jarvis, 1992).

Ramirez-Villapudua \& Munnecke (1988) observaram que matérias orgânicas que foram eficientes para determinados patógenos não foram eficientes para 0 amarelecimento em repolho causado pelo fungo Fusarium oxysporum $f$. sp. conglutinans. Verificaram que a incorporação de resíduos de crucíferas foi excelente, tanto para o tratamento associado a solarização, como em tratamento mantido em local sombreado, sendo mais eficiente do que somente a solarização ou tratamento mantido na sombra, indicando que resíduos de crucíferas foram mais eficientes do que a solarização. Gases da decomposição do repolho podem ter papel importante no declínio de propágulos de $F$. oxysporum $\mathrm{f}$. sp. conglutinans, sendo possivel que esses gases estariam primeiramente estimulando a germinação de propágulos. A germinação de propágulos é o estádio mais delicado e, na contínua exposição aos compostos voláteis, são suscetíveis ao ataque de antagonistas da microbiota do solo, que é estimulada ou tolerante a esses gases.

Gamliel \& Stapleton (1993a) identificaram compostos voláteis produzidos em solos solarizados com incorporação de resíduos de repolho e também avaliaram o efeito do tratamento sobre Pythium ultimum e Sclerotinia rolfsii. Os principais compostos detectados nos solos solarizados com incorporação de resíduos de repolho foram aldeídos (formaldeído e acetaldeído) e compostos de enxofre, incluindo isotiocianatos. O tratamento onde foi feito somente a solarização foi eficiente para a diminuição de patógenos quando a temperatura máxima atingiu $45^{\circ} \mathrm{C}$, mas ineficiente quando a temperatura máxima foi $38^{\circ} \mathrm{C}$. Nesta mesma temperatura onde a solarização foi associada à incorporação de resíduos de repolho houve significante redução de patógenos no solo. Observaram também um aumento na atividade microbiana quando solos foram expostos a vapores resultantes de solos solarizados ou não, associados a 
incorporação de resíduos de repolho, quando comparada a atividade microbiana em solos onde não houve incorporação da matéria orgânica.

Composto de casca de madeira usado no cultivo de Poinsettia apresentou-se supressivo a Pythium spp. e Rhizoctonia solani, causadores de podridão de raizes e da coroa, além de promover um melhor crescimento e qualidade das plantas. A utilização desse material poderia eventualmente eliminar o tratamento com vapor e a utilização de fungicidas no solo. Um estudo mais detalhado é necessário para verificar a presença de compostos naturais na casca de madeira, que são liberados para o solo em quantidades suficientes para controlar diversos patógenos (Daft et al., 1979).

Martin \& Hancock (1986) concluíram em seu trabalho que a supressividade de solos ao $P$. ultimum ocorre devido ao aumento na salinidade quando concentrações de cloro chegam a niveis que inibem suas atividades saprofiticas, favorecendo a habilidade competitiva saprofitica de $P$. oligandrum e aumentando então sua população. A ocorrência da supressividade a $P$. ultimum depende da densidade do inóculo e a textura do solo, o que está relacionado a predisposição do tipo de solo a problemas de salinidade.

Compostos originados da coleta seletiva de lixo doméstico promovem uma certa proteção de plantas contra patógenos de solo, ficando obscuro o modo de ação da supressividade (Schueler et al., 1989). O efeito da supressividade depende do tempo de decomposição e origem do composto. Compostos de vegetais apresentaram-se supressivos a $R$. solani, onde teve-se uma redução de 30 a 70\% do patógeno após um tempo longo de decomposição de cinco a sete meses, mas o período curto de um mês estimulou o crescimento do patógeno (Tuitert et al., 1998). Desenvolvimento da supressividade a $R$. solani com o aumento da idade do composto também foi constatado em composto de casca de madeira (Nelson et al., 1983) e composto de lodo de esgoto para damping-off causado por $R$. solani e Pythium spp. em estufas e viveiros (Kuter et al., 1988). O lodo de esgoto estimulou o desenvolvimento de plantas de sorgo, tanto na presença, como na ausência do patógeno, caracterizando um estímulo nutricional, e também apresentou redução da podridão de raiz do sorgo causada por Pythium arrhenomanes (Bettiol \& Krugner, 1984). Já Millner et al. (1982) não obtiveram 
controle da doença em ervilha e feijão causado por Fusarium solani e Pythium aphanidermatum; doenças em ervilha, feijão e algodão causadas por $P$. ultimum $\mathrm{e}$ Thielaviopsis basicola aumentaram com a adição do composto. Obteve-se uma significante redução de doenças em alface causadas por Sclerotinia minor; feijão, algodão e rabanete causada por $R$. solani; em ervilha por Aphanomyces euteiches e em pimentão causada por Phytophthora capsici. Lumsdem et al. (1983) verificaram que a supressividade a doenças causadas por Pythium spp. e Rhizoctonia spp. foi melhorada com o aumento do tempo entre a incorporação do composto de lodo de esgoto e o plantio. Não ocorreu uma diminuição da sobrevivência de $S$. minor, $R$. solani e Pythium spp. com a utilização do composto, mas a atividade desses patógenos pode ter sido afetada com o aumento da atividade microbiana estimulada pela adição do composto no solo.

Dois resíduos de cana de açúcar: mistura de bagaço e torta de filtro; bagaço, vinhaça e torta de filtro apresentaram-se supressivos a $P$. aphanidermatum, reduzindo a densidade de inóculo do patógeno e incidência de doença em plântulas de pepino. A supressividade foi perdida quando se aqueceu os compostos, indicando o envolvimento de fatores biológicos no efeito supressivo sobre $P$. aphanidermatum (Theodoro \& Toribio, 1995).

Gamliel \& Stapleton (1993b) verificaram que a combinação de adubos com a solarização foi muito eficiente no controle de Meloidogyne incognita e P. ultimum, resultando no aumento da produtividade em campos de alface e sugerem que a utilização de resíduos de plantas, adubo verde e fertilizantes pode ser uma forma alternativa não química quando a solarização isolada não promover um controle adequado dos patógenos em questão. Os autores obtiveram redução nas unidades formadoras de colônias de $P$. ultimum através da solarização observando também a supressividade dos solos solarizados para o estabelecimento do fungo na rizosfera. O esterco de galinha incorporado ao solo associado a solarização apresentou-se eficiente no controle de $M$. incognita em alface. A incorporação de esterco de galinha ou fosfato de amônia sem a solarização resultou em leve redução de $M$. incognita e número de propágulo de $P$. ultimum. As temperaturas em solos solarizados com adição de composto apresentaram 
2 a $3^{\circ} \mathrm{C}$ a mais quando comparados com solos solarizados sem a incorporação do adubo. A adição de adubo após a solarização apresentou efeito negativo no crescimento de plantas, o que pode estar relacionado a decomposição mais lenta do adubo no solo devido a redução de bactérias nitrificadoras e ou a liberação de compostos fitotóxicos durante as primeiras semanas de crescimento das plantas. 


\section{MATERIAL E MÉTODOS}

\subsection{Ensaios em casa de vegetação}

\subsubsection{Efeito de fontes de matéria orgânica no crescimento micelial de Pythium sp. e emergência de pepino.}

A supressividade resultante da produção de metabólitos voláteis por diferentes matérias orgânicas foi avaliada por meio da inibição no crescimento micelial de Pythium sp., isolado de crisântemo. Foram utilizadas as seguintes matérias orgânicas: biossólido originário da Estação de Tratamento de Esgoto de Franca (ETE-Franca); cama-defrango; casca de Pinus; composto produzido com resíduos de flores com três semanas, três meses e seis meses de decomposição em leiras, obtidos em cultivo comercial de plantas ornamentais; folhas de repolho e de couve-flor. Os materiais foram secos em estufa a $55^{\circ} \mathrm{C}$ por um período de $96 \mathrm{~h}$, resultando na umidade final de 9,$98 ; 5,93 ; 16,43$; 5,$32 ; 3,77 ; 3,85 ; 72,75$ e $61,74 \%$, respectivamente. Posteriormente, foi feita uma moagem antes da incorporação ao solo.

Discos de meio de cultura $(0,6 \mathrm{~mm}$ de diâmetro), contendo micélio de Pythium sp., foram transferidos para placas ( $9 \mathrm{~cm}$ de diâmetro) com meio de cultura de BDA. Após a repicagem do fungo, as tampas das placas foram substituídas por uma tela de nylon, que permite trocas gasosas. Em seguida, as placas foram enterradas, na posição vertical, em vasos (capacidade de $5 \mathrm{~L}$ ) contendo solo (obtido em barranco, com umidade de $6,37 \%)$ misturado com os diferentes resíduos nas concentrações de 10 e $20 \%(\mathrm{v} / \mathrm{v})$. Foi colocada uma placa por vaso, em cinco repetições. A mistura foi umedecida com $300 \mathrm{~mL}$ de água por vaso. Os vasos foram envoltos individualmente por sacos plásticos 
negros, fechados e mantidos em sala com temperatura de $25 \pm 2^{\circ} \mathrm{C}$. A supressividade foi avaliada pelo crescimento micelial do patógeno, por meio da medição de dois diâmentros perpendiculares. O experimento foi repetido três vezes.

Após terem sido realizadas as avaliações do crescimento micelial do patógeno, os vasos foram transferidos para casa de vegetação, onde foi adicionado $5 \mathrm{~g}$ de aveia na superfície do solo contido em cada vaso, com a finalidade de estimular a população nativa de Pythium spp., e semeadas cinco sementes de pepino do híbrido Safira. Após 6 dias, foi feita a avaliação da emergência de plântulas de pepino.

\subsubsection{Controle do tombamento de pepino, causado por Pythium spp., com a utilização de diferentes fontes de matéria orgânica}

Para avaliar o efeito dos resíduos na ocorrência de tombamento de plântulas de pepino, causado por Pythium spp., foi utilizado o método descrito por Lourd et al. (12). Os resíduos testados foram: biossólidos da ETE-Franca, cama-de-frango, casca de Pinus, composto produzido com resíduos de flores com três semanas, três meses e seis meses de decomposição em leiras, folhas de repolho e de couve-flor. Os materiais foram secos em estufa a $55^{\circ} \mathrm{C}$ por um período de $144 \mathrm{~h}$, resultando na umidade final de 3,$52 ; 4,59$; 3,$96 ; 3,10 ; 2,15 ; 2,18 ; 6,75$ e $3,88 \%$, respectivamente. Foi realizada uma moagem antes da incorporação ao solo naturalmente infestado com Pythium spp. (umidade de 14,41\%), obtido em cultivo comercial de crisântemos.

O solo infestado foi misturado com as diferentes matérias orgânicas nas concentrações de 10 e $20 \%$ (v/v), e mantido em sacos plásticos (400 g de solo/saco), durante 20 dias, em cinco repetições para cada tratamento. Após esse período, foi adicionado $35 \mathrm{~g} . \mathrm{L}^{-1}$ de farelo de aveia a cada mistura e após $48 \mathrm{~h}$ colocado no colo de plântulas de pepino.

As plântulas de pepino do híbrido Safira foram obtidas em solo autoclavado por $1 \mathrm{~h}, 1 \mathrm{~atm}, 120^{\circ} \mathrm{C}$, em dois dias consecutivos, contido em vasos. Cada vaso com capacidade de $600 \mathrm{~mL}$, continha 10 plântulas de pepino, com cinco dias de idade. 
A avaliação foi realizada pela contagem de plântulas de pepino tombadas, após $72 \mathrm{~h}$ da colocação dos solos tratados no colo das plântulas. Isolamentos do patógeno foram feitos para confirmar a presença de Pythium.

\subsubsection{Comparação entre diferentes camas-de-frango}

Devido à intensa utilização de tratamentos químicos na produção convencional de frangos, camas-de-frango obtidas de diferentes formas de produção foram comparadas quanto ao controle de Pythium spp. As camas-de-frango foram obtidas de uma granja com produção orgânica (sistema Yamaguishi; umidade de 16,40\%) e duas produções convencionais (umidade de 64,78 e 29,44\%). Para verificação do controle do patógeno foi utilizado o método descrito por Lourd et al. (12). No colo de plântulas de pepino do híbrido Safira foi colocado solo naturalmente infestado com Pythium, misturado com aveia (35g. $\left.\mathrm{L}^{-1}\right)$ e as diferentes camas-de-frango, nas concentrações de 10 e $20 \%$ (peso/peso). A testemunha foi constituída por plântulas que receberam somente solo infestado misturado com aveia. Cada tratamento foi repetido dez vezes, sendo cada repetição constituída por um vaso com dez plântulas. A avaliação foi realizada pela contagem de plântulas apresentando o sintoma típico de tombamento causado pelo patógeno.

Após realizada a avaliação, foram novamente semeadas 10 sementes de pepino por vaso para verificar se havia efeito sobre a emergência das plantas.

\subsection{Ensaios em campo}

\subsubsection{Solarização do solo associada a matérias orgânicas para o controle de Pythium sp. em crisântemo}

O experimento foi conduzido numa área de $460,8 \mathrm{~m}^{2}$, que é comercialmente cultivada com crisântemos de corte da Fazenda Terra Viva, localizada no município de Santo Antônio de Posse/SP (latitude $22^{\circ} 37^{\prime}$ sul, longitude 46 W. Gr.). 
O delineamento experimental adotado foi o casualizado em blocos, com três repetições. Os tratamentos se constituíram da combinação de dois fatores: solarização (solarizado ou não) e fontes de matéria orgânica (biossólidos da ETE-Franca, cama-defrango, casca de Pinus e sem matéria orgânica). Cada parcela foi constituída por dois canteiros com 1,2 m de largura e $6 \mathrm{~m}$ de comprimento, espaçados por $40 \mathrm{~cm}$.

\subsubsection{Incorporação de matérias orgânicas e solarização}

As diferentes matérias orgânicas foram incorporadas manualmente, na profundidade de $20 \mathrm{~cm}$, na quantidade de $1 \mathrm{~kg}$ matéria seca $/ \mathrm{m}^{2}$. As matérias orgânicas e o solo foram caracterizados por meio de análise química completa. Em todos os tratamentos com adição de matéria orgânica, os materiais foram incorporados juntamente com a colocação do plástico para solarização.

A solarização foi realizada com a cobertura do solo, durante 1 mês aproximadamente (de 11 de fevereiro a 17 de março de 1999), com um filme de polietileno transparente com $100 \mu \mathrm{m}$ de espessura. Durante a solarização, a temperatura dos solos dos tratamentos foi avaliada em intervalos de 1 hora, na profundidade de 10 cm, com auxílio de "data loggers", em uma repetição por tratamento.

\subsubsection{Coleta das amostras de solo}

As amostras de solo foram coletadas na profundidade de $20 \mathrm{~cm}$, com auxílio de um trado com $2 \mathrm{~cm}$ de diâmetro, sendo obtidas 15 sub amostras em cada canteiro de cada parcela, totalizando duas amostras compostas por parcela. As amostras foram coletadas antes da solarização e incorporação das diferentes matérias orgânicas; 15 e 35 dias após a incorporação; 41 e 88 dias após o plantio do crisântemo, durante o ciclo de cultivo, ou seja: 91 e 138 dias após incorporação de matéria orgânica, respectivamente. A coleta aos 15 dias foi feita durante a solarização, com a retirada e imediata recolocação do plástico. A coleta aos 35 dias foi feita após o término da solarização. 


\subsubsection{Umidade do solo}

No decorrer do experimento, amostras de solo foram analisadas para determinar a umidade nos diferentes tratamentos. A umidade foi determinada secando-se o solo durante $24 \mathrm{~h}$ a $100^{\circ} \mathrm{C}$, em estufa.

\subsubsection{5 pH e condutividade elétrica do solo}

Amostras de solo dos diferentes tratamentos foram analisados para determinar o $\mathrm{pH}$ e a condutividade elétrica no decorrer do experimento. O preparo das amostras foi realizado em água destilada (1:1,5 água destilada, $v / v)$. As amostras foram coletadas antes da solarização e incorporação das diferentes matérias orgânicas, 15 e 35 dias após a incorporação e 41 e 88 dias após o plantio do crisântemo, durante um ciclo de crisântemo.

\subsubsection{Atividade microbiana do solo}

Através dos métodos de hidrólise de diacetato de fluoresceina (FDA) e desprendimento de $\mathrm{CO}_{2}$ foi avaliada a atividade microbiana do solo, segundo Boehm \& Hoitink (1992) e Grisi (1978), respectivamente. As análises foram realizadas antes da incorporação da matéria orgânica no solo, 15 dias após a incorporação, 35 dias após a incorporação (que foi a data da retirada dos plásticos das parcelas solarizadas) e duas vezes durante o ciclo do crisântemo: 41 e 88 dias após o plantio das mudas.

Para a determinação da hidrólise de FDA, amostras de 5 g de solo de cada parcela foram colocados em frascos de Erlenmeyer $(250 \mathrm{~mL})$, juntamente com $20 \mathrm{~mL}$ de tampão fosfato de potássio $60 \mathrm{mM}\left(8,7 \mathrm{~g}\right.$ de $\mathrm{K}_{2} \mathrm{HPO}_{4}$ e $1,3 \mathrm{~g}$ de $\mathrm{KH}_{2} \mathrm{PO}_{4} / \mathrm{L}$ de água destilada; $\mathrm{pH}$ 7,6). A reação de hidrólise de FDA foi iniciada adicionando-se $0,2 \mathrm{~mL}$ $(400 \mu \mathrm{g})$ de solução estoque de FDA ( $2 \mathrm{mg} \cdot \mathrm{mL}^{-1}$ acetona). As amostras foram incubadas durante 20 minutos em agitador $(200 \mathrm{rpm})$ a $25^{\circ} \mathrm{C}$ e, em seguida, a reação foi interrompida através da adição de $20 \mathrm{~mL}$ de acetona por frasco. O material foi então 
filtrado em papel Whatman $\mathrm{n}^{\circ} 1$ e os filtrados recolhidos em tubos de cultura para posterior determinação da absorbância $(490 \mathrm{~nm})$ em espectrofotômetro. Os filtrados foram acondicionados em geladeira, tampados para evitar a evaporação da acetona. A concentração de FDA hidrolisado ( $\mu \mathrm{m}$ FDA hidrolisado/g solo seco) foi obtida através da determinação da curva padrão. Essa curva foi obtida adicionando-se FDA nas quantidades de $0,100,200,300,400 \mu \mathrm{m}$ em $5 \mathrm{~g}$ de solo e $15 \mathrm{~mL}$ de tampão fosfato, em duas repetições. Prosseguiu-se a metodologia acima para se obter a curva padrão entre 0 FDA hidrolisado e a absorbância.

Para determinar a respiração microbiana (desprendimento de $\mathrm{CO}_{2}$ ), $100 \mathrm{~g}$ de solo das parcelas foram incubados em recipientes hermeticamente fechados contendo $10 \mathrm{~mL}$ de $\mathrm{KOH} 0,5 \mathrm{~N}$, no escuro, a $25^{\circ} \mathrm{C}$. Após 13 dias de incubação, o $\mathrm{KOH}$ foi titulado com $\mathrm{HCl}$, segundo o método descrito por Grisi (1978), para a determinação da quantidade total de $\mathrm{CO}_{2}$ desprendido.

\subsubsection{Plantas daninhas}

A avaliação da ocorrência de plantas daninhas foi realizada 34 dias após a incorporção das diferentes matérias orgânicas no solo, ou seja, após o término da solarização. A área amostrada foi de $0,75 \mathrm{~m}^{2}$, em três repetições por parcela. As plantas daninhas obtidas foram pesadas logo que foram retiradas do campo e, em seguida as plantas foram colocadas em sacos de papel e secadas em estufa a $60^{\circ} \mathrm{C}$ até atingir peso constante, para a determinação do peso de matéria seca.

\subsubsection{Resistência do solo à penetração}

Após o período de solarização, foi avaliada a resistência à penetração do solo para constatar se ocorreram alterações nas propriedades fisicas do solo nos diferentes tratamentos. A avaliação foi realizada com o auxílio de penetrômetro manual. 


\subsubsection{Controle do patógeno}

No decorrer do ciclo da cultura, foi realizada a avaliação da ocorrência de plantas com sintomas de murcha e podridão radicular. Plantas doentes foram levadas ao laboratório onde foi realizado o isolamento em meio ágar-água, seguido de cultivo em meio de BDA.

A avaliação da população de Pythium spp. no solo também foi realizada pelo método descrito por Lourd et al. (1986). Para tanto, foi feita a semeadura de pepino (híbrido Safira; 10 sementes/vaso com $600 \mathrm{~mL}$ de capacidade) em solo auclavado por 1 $\mathrm{h}$, a $120^{\circ} \mathrm{C}$ e $1 \mathrm{~atm}$, em dois dias. As amostras de solo a serem testadas foram misturadas com farelo de aveia ( $35 \mathrm{~g} / \mathrm{L}), 48$ horas antes de serem colocadas no colo das plântulas de pepino, em estádio de cotilédones abertos. $O$ farelo de aveia contribui para o desenvolvimento do patógeno.

Foram utilizados dois vasos para cada amostra composta de solo, sendo retiradas duas amostras compostas (mistura de 15 sub amostras) em cada parcela. Os vasos com plântulas de pepino foram mantidos em casa de vegetação e a avaliação foi realizada pela contagem de plântulas apresentando sintoma típico de tombamento causado por Pythium spp.

\subsubsection{Altura de plantas de crisântemo e peso do sistema radicular}

Após 69 dias do plantio de mudas de crisântemo no campo ou seja, 119 dias após incorporação das diferentes matérias orgânicas, foram coletadas 5 plantas de crisântemo por parcela, para avaliação da altura da parte aérea e peso do sistema radicular. Durante o período de colheita foram realizadas avaliações da qualidade e produtividade nos diferentes tratamentos. 
3.2.2 Solarização do solo associada a matérias orgânicas para o controle de Pythium spp. em pepino

O experimento foi conduzido em área experimental da Embrapa Meio Ambiente (Jaguariúna, SP, latitude $22^{\circ} 41^{\prime}$ sul, longitude $47^{\circ} \mathrm{W}$. Gr. e altitude $570,438 \mathrm{~m}$ ) com o objetivo de avaliar o efeito da incorporação de diferentes fontes de matéria orgânica e solarização no controle de Pythium spp. em pepino.

Inicialmente, $15 \mathrm{~kg}$ de solo infestado com Pythium spp. obtido em cultivo comercial de crisântemo foi incorporado por metro quadrado da área experimental. Farelo de aveia também foi incorporado ao solo $\left(400 \mathrm{~g} / \mathrm{m}^{2}\right)$, antes da cobertura com filme plástico, para aumentar a quantidade de inóculo.

As matérias orgânicas utilizadas foram: biossólidos da ETE-Franca, cama-defrango e casca de Pinus, que foram incorporadas manualmente, na profundidade de 10 $\mathrm{cm}$ e na quantidade de $1 \mathrm{~kg}$ de matéria orgânica seca por $\mathrm{m}^{2}$. A solarização consistiu na cobertura do solo com um filme de polietileno transparente ( $50 \mu \mathrm{m}$ de espessura), por 42 dias (de 22 de setembro 3 de novembro/1999).

Cada parcela foi constituída por uma área de $1 \mathrm{~m} \mathrm{x} 3 \mathrm{~m}$, num delineamento experimental "strip plot", casualizado em blocos, com três repetições, de forma que os tratamentos solarizados foram agrupados, sendo a colocação de plástico numa área de $3,5 \times 7 \mathrm{~m}$ por bloco, com a finalidade de eliminar o efeito de borda.

A semeadura foi feita logo após a retirada do plástico, em quatro linhas por parcela, com espaçamento de $15 \mathrm{~cm}$ entre linhas e $8 \mathrm{~cm}$ entre plantas de pepino híbrido Safira, totalizando 35 sementes por linha.

Amostras de solo foram coletadas após o período de solarização para avaliação da umidade e atividade microbiana, que foram realizadas pelo método da hidrólise de diacetato de fluoresceina (Boehm \& Hoitink, 1992) e desprendimento de $\mathrm{CO}_{2}$ (Grisi, 1978).

Para verificação do controle do patógeno no campo, foi avaliado o número de plantas sadias por parcela, 15 dias após a semeadura. Além disso, foram feitos 
isolamentos de Pythium spp. dos solos das parcelas, através da técnica descrita por Hine \& Luna (1963) modificada. Cubos de $3 \mathrm{~mm}$ de batata foram mergulhados em solução contendo $100 \mathrm{ppm}$ de sulfato de estreptomicina e $20 \mathrm{ppm}$ de benomyl, durante 1 hora. Solos dos diferentes tratamentos foram colocados em placas de Petri e umedecidos. Os cubos de batata (10 cubos por placa; três placas por parcela) foram colocados nos solos e incubados por 12 a $15 \mathrm{~h}$ a $31^{\circ} \mathrm{C}$. Em seguida, os cubos foram removidos, lavados em água de torneira e plaqueados em ágar-água suplementado com $100 \mathrm{ppm}$ de estreptomicina e $20 \mathrm{ppm}$ de benomyl. A avaliação foi realizada pela determinação da porcentagem de recuperação do patógeno nos cubos.

\subsection{Identificação de espécies de Pythium}

Os isolados obtidos foram mantidos em meio de cultura BDA no decorrer dos experimentos e a identificação foi realizada no Instituto de Botânica de São Paulo.

Discos de micélio com Pythium spp. foram transferidos para o meio de cultura CMA + ppe (corn meal agar com adição de penicilina, pimaricina e estreptomicina). Após o desenvolvimento de micélio, discos foram retirados e colocados em água destilada com sementes de sorgo previamente fervidas por 5 minutos para evitar a germinação destes. Durante uma semana o material foi observado para a formação de estruturas reprodutivas. Aos isolados que não se apresentaram férteis foi adicionado pepino. Mesmo após esse procedimento, alguns isolados não formaram estruturas reprodutivas. 


\section{RESULTADOS E DISCUSSÃO}

\subsection{Ensaios em casa de vegetação}

\subsubsection{Efeito de fontes de matéria orgânica no crescimento micelial de Pythium sp. e emergência de pepino.}

Dos resíduos incorporados ao solo e testados quanto à inibição do crescimento micelial de Pythium spp., somente as folhas de couve-flor na concentração de $20 \%$ promoveram uma redução no crescimento. Os demais resíduos não diferiram estatisticamente entre si (Tabela 1).

Apesar de ter sido feita uma secagem dos materiais, previamente à incorporação ao solo, as folhas de couve-flor apresentaram um alto teor de umidade $(61,74 \%)$. Entretanto, mesmo com um teor de umidade maior do que os demais, os resultados obtidos com as folhas de couve-flor foram superiores aos outros tratamentos. Provavelmente, a produção de compostos voláteis foi a responsável pela inibição do crescimento micelial de Pythium observada com a incorporação de folhas de couve-flor (Tabela1).

A presença de metabólitos voláteis, tóxicos a fitopatógenos, em espécies de Brassica, é conhecida há anos, quando Walker et al. (1937) observaram seus efeitos em diversos fungos, em testes cuja finalidade era demonstrar os mecanismos de resistência dessas plantas aos fitopatógenos. Entretanto, a produção de glucosinolatos depende, segundo Kirkegaard et al. (1998), de diversos fatores como: espécie da planta, idade, condições de cultivo e tipo de tecido vegetal, sendo que tais fatores devem ser considerados na utilização prática do material. 
Tabela 1. Efeito de fontes de matéria orgânica no crescimento micelial de Pythium sp.

\begin{tabular}{lccc}
\hline Tratamento & \multicolumn{2}{c}{ Concentração } & Média \\
& \multicolumn{2}{c}{$(\%)$} & \\
\cline { 2 - 3 } & $7,90 \mathrm{aA}$ & $6,74 \mathrm{aA}$ & $7,31 \mathrm{a}$ \\
\hline Biossólido & $7,72 \mathrm{aA}$ & $6,40 \mathrm{aA}$ & $7,04 \mathrm{a}$ \\
Cama-de-frango & $7,16 \mathrm{aA}$ & $7,26 \mathrm{aA}$ & $7,21 \mathrm{a}$ \\
Casca de Pinus & $6,62 \mathrm{aA}$ & $3,15 \mathrm{bB}$ & $4,75 \mathrm{~b}$ \\
Folhas de couve-flor & $7,90 \mathrm{aA}$ & $6,59 \mathrm{aA}$ & $7,23 \mathrm{a}$ \\
Folhas de repolho & $7,58 \mathrm{aA}$ & $7,07 \mathrm{aA}$ & $7,32 \mathrm{a}$ \\
Composto com 3 semanas & $7,42 \mathrm{aA}$ & $7,80 \mathrm{aA}$ & $7,61 \mathrm{a}$ \\
Composto com 3 meses & $7,46 \mathrm{aA}$ & $7,90 \mathrm{aA}$ & $7,68 \mathrm{a}$ \\
Composto com 6 meses & $7,46 \mathrm{~A}$ & $6,53 \mathrm{~B}$ & \\
\hline Médias & &
\end{tabular}

Médias seguidas de mesma letra minúscula na coluna e letra maiúscula na linha não diferem entre si pelo teste Duncan ao nível de 0,05 de probabilidade. Para a análise estatística, os dados foram transformados em $(x+1)^{-2}$.

Quando as misturas de solo e matérias orgânicas receberam aveia para estimular a população nativa de Pythium spp. do solo, verificou-se que além das folhas de couveflor, cama-de-frango e biossólido incorporados na concentração de $20 \%$ promoveram uma maior porcentagem de emergência de plântulas de pepino (Tabela 2). Desse modo, outros mecanismos diferentes da produção de metabólitos voláteis podem estar atuando após a incorporação de cama-de-frango e biossólidos. 
Tabela 2. Efeito de fontes de matéria orgânica na emergência de plântulas de pepino.

\begin{tabular}{|c|c|c|}
\hline Tratamento & $\begin{array}{c}\text { Concentração } \\
(\%)\end{array}$ & $\begin{array}{c}\text { Emergência de plântulas } \\
\text { (\%) }\end{array}$ \\
\hline \multirow[t]{2}{*}{ Biossólido } & 10 & $24,0 \mathrm{C}$ \\
\hline & 20 & $56,0 \mathrm{~B}$ \\
\hline \multirow[t]{2}{*}{ Cama-de-frango } & 10 & $28,0 \mathrm{C}$ \\
\hline & 20 & $84,0 \mathrm{~A}$ \\
\hline \multirow[t]{2}{*}{ Casca de Pinus } & 10 & 0,0 \\
\hline & 20 & 0,0 \\
\hline \multirow[t]{2}{*}{ Folhas de couve-flor } & 10 & $48,0 \mathrm{~B}$ \\
\hline & 20 & $80,0 \mathrm{~A}$ \\
\hline \multirow[t]{2}{*}{ Folhas de repolho } & 10 & $8,0 \mathrm{D}$ \\
\hline & 20 & $4,0 \mathrm{D}$ \\
\hline \multirow[t]{2}{*}{ Composto com 3 semanas } & 10 & 0,0 \\
\hline & 20 & $4,0 \mathrm{D}$ \\
\hline \multirow[t]{2}{*}{ Composto com 3 meses } & 10 & $4,0 \mathrm{D}$ \\
\hline & 20 & 0,0 \\
\hline \multirow[t]{2}{*}{ Composto com 6 meses } & 10 & 0,0 \\
\hline & 20 & 0,0 \\
\hline Testemunha com solo & - & 0,0 \\
\hline
\end{tabular}

Médias de emergência seguidas de mesma letra não diferem entre si pelo teste Duncan ao nível de 0,05 de probabilidade. Os tratamentos que não apresentaram tombamento de plântulas de pepino não foram incluídos na análise estatística. 
4.1.2 Controle do tombamento de pepino, causado por Pythium spp., com a utilização de diferentes fontes de matéria orgânica

Folhas de couve-flor, biossólido e cama-de-frango também apresentaram controle total do patógeno nas concentrações de 10 e $20 \%$, quando foi realizada a avaliação pelo método descrito por Lourd et al. (1986) (Tabela 3). A casca de Pinus e os compostos produzidos com resíduos de flores não tiveram efeito sobre o patógeno, apresentando inclusive algum estímulo ao tombamento de plântulas em relação à testemunha (Tabela 3).

Os resultados obtidos no teste de tombamento de plântulas (Tabela 3) estão de acordo com os obtidos no teste de emergência de plântulas de pepino em solos tratados com resíduos (Tabela 2), onde as folhas de couve-flor, a cama-de-frango e o biossólido apresentaram controle do patógeno. A supressividade de solos a fitopatógenos conferida por fontes de matéria orgânica pode ser resultante, tanto de alterações na composição e atividade da microbiota, quanto das características físicas e químicas dos solos (Rodríguez-Kábana \& Calvet, 1994). A redução da incidência da doença pode ainda ser atribuída ao aumento das defesas da planta hospedeira, ou devida à inibição direta da atividade ou crescimento do patógeno.

Resultados semelhantes foram obtidos por Bettiol \& Krugner (1984), que observaram que o lodo de esgoto apresentou redução da podridão de raiz do sorgo causada por Pythium arrhenomanes. Para Millner et al. (1982), o efeito de biossólidos para algumas doenças é evidente no primeiro ciclo de cultivo e mantido constante nos cultivos subsequentes; para outras doenças, o efeito não é imediato, mas a longo prazo. 
Tabela 3. Efeito de fontes de matéria orgânica no tombamento de plântulas de pepino, causado por Pythium spp.

\begin{tabular}{lcc}
\hline Tratamento* & $\begin{array}{c}\text { Concentração } \\
(\%)\end{array}$ & $\begin{array}{c}\text { Tombamento de plântulas } \\
(\%)\end{array}$ \\
\hline Biossólido & 10 & 0 \\
Cama-de-frango & 20 & 0 \\
Casca de Pinus & 10 & 0 \\
Folhas de couve-flor & 20 & 0 \\
Folhas de repolho & 10 & $75,62 \mathrm{AB}$ \\
Composto com 3 semanas & 20 & $76,34 \mathrm{AB}$ \\
Composto com 3 meses & 10 & 0 \\
& 20 & 0 \\
Composto com 6 meses & 10 & $67,18 \mathrm{BC}$ \\
Testemunha com solo & 20 & $18,10 \mathrm{E}$ \\
\hline
\end{tabular}

* As matérias orgânicas: biossólidos, cama-de-frango e folhas de couve-flor não apresentaram tombamento de plântulas de pepino e portanto não foram incluídas na análise estatística. Médias seguidas de mesma letra não diferem entre si pelo teste Duncan ao nivel de 0,05 de probabilidade. 


\subsubsection{Comparação entre diferentes camas-de-frango}

Os solos tratados com os três tipos de cama-de-frango não apresentaram tombamento de plântulas, fato apenas observado nas testemunhas com solo infestado, onde a ocorrência da doença foi em $37,67 \%$ das plântulas (Tabela 4). Da mesma forma, o resultado obtido na avaliação de emergência de plântulas de pepino demonstrou que os três materiais diferiram significativamente da testemunha sem adição de matéria orgânica. Assim sendo, os tratamentos químicos utilizados na produção convencional de frangos não são os responsáveis pelo controle do patógeno.

Tabela 4. Comparação entre camas-de-frango obtidas de diferentes sistemas de produção quanto ao tombamento causado por Pythium spp. e a emergência de plântulas de pepino.

\begin{tabular}{lccc}
\hline Tratamento & $\begin{array}{c}\text { Concentração } \\
(\%)\end{array}$ & $\begin{array}{c}\text { Tombamento } \\
\text { de plântulas } \\
(\%)\end{array}$ & $\begin{array}{c}\text { Emergência } \\
\text { de plântulas } \\
(\%)\end{array}$ \\
\hline Cama-de-frango de produção orgânica & 10 & 0 & $77,0 \mathrm{BC}$ \\
& 20 & 0 & $74,0 \mathrm{C}$ \\
Cama-de-frango de produção convencional 1 & 10 & 0 & $90,0 \mathrm{~A}$ \\
Cama-de-frango de produção convencional 2 & 20 & 0 & $84,0 \mathrm{ABC}$ \\
& 10 & 0 & $84,0 \mathrm{ABC}$ \\
Solo autoclavado & 20 & 0 & $89,0 \mathrm{~A}$ \\
Testemunha infestada & - & 0 & $88,0 \mathrm{AB}$ \\
\hline
\end{tabular}

Para análise os estatística dados foram transformados em $\mathrm{x}^{2}$. Médias seguidas de mesma letra não diferem entre si pelo teste Duncan ao nível de 0,05 de probabilidade. 


\subsection{Ensaios em campo}

4.2.1 Solarização do solo associada a matérias orgânicas para o controle de Pythium sp. em crisântemo

\subsubsection{Análises químicas do solo e das matérias orgânicas.}

Nas tabelas 5 e 6 estão apresentados os resultados das análises quimicas do solo do campo onde foi realizado o experimento e das diferentes matérias orgânicas incorporadas nas parcelas, respectivamente. As três matérias orgânicas foram escolhidas devido aos resultados apresentados nos testes em casa de vegetação e nas diferenças quanto à relação $\mathrm{C} / \mathrm{N}$ (Tabela 6 ).

De modo geral, o biossólido apresenta maiores teores de nutrientes do que as demais matérias orgânicas (Tabela 6), exceto potássio, que é uma característica frequente nesse tipo de material (Bettiol \& Camargo, 2000). 
Tabela 5. Análise química do solo do campo utilizado para a realização do ensaio de solarização do solo associada a matérias orgânicas para o controle de Pythium spp. em crisântemo.

\begin{tabular}{|c|c|}
\hline Característica & Solo \\
\hline $\mathrm{pH}\left(\mathrm{CaCl}_{2}\right)$ & 5,7 \\
\hline $\mathrm{pH}\left(\mathrm{H}_{2} \mathrm{O}\right)$ & 6,5 \\
\hline $\mathrm{pH}(\mathrm{SMP})$ & 6,65 \\
\hline $\mathrm{H}+\mathrm{Al} \quad(\mathrm{mEq})$ & 2,1 \\
\hline $\mathrm{Al}(\mathrm{mEq})$ & $\mathrm{ALD}^{1}$ \\
\hline $\mathrm{Ca}(\mathrm{mEq})$ & 5,0 \\
\hline $\mathrm{Mg}(\mathrm{mEq})$ & 1,8 \\
\hline $\mathrm{K}(\mathrm{mEq})$ & 0,35 \\
\hline P (ppm) (Mehlich) & 95 \\
\hline $\mathrm{P}(\mathrm{ppm})$ (Resina) & 175 \\
\hline $\mathrm{C}\left(\mathrm{g} / \mathrm{dm}^{3}\right)$ & 16 \\
\hline Matéria orgânica $\left(\mathrm{g} / \mathrm{dm}^{3}\right)$ & 28 \\
\hline Soma de bases (mEq) & 7,15 \\
\hline Capacidade de troca catiônica (CTC, mEq) & 9,25 \\
\hline Saturação de bases (V \%) & 77,30 \\
\hline Cálcio / Magnésio & 2,8 \\
\hline $\mathrm{S}(\mathrm{ppm})$ & 2,8 \\
\hline $\mathrm{Na}(\mathrm{ppm})$ & 4,5 \\
\hline $\mathrm{B}(\mathrm{ppm})$ & 0,2 \\
\hline $\mathrm{Fe}(\mathrm{ppm})$ & 47,8 \\
\hline $\mathrm{Mn}(\mathrm{ppm})$ & 57,4 \\
\hline $\mathrm{Cu}(\mathrm{ppm})$ & 3 \\
\hline $\mathrm{Zn}(\mathrm{ppm})$ & 20 \\
\hline$N(\%)$ & 0,26 \\
\hline Relação C/N & $6 / 1$ \\
\hline
\end{tabular}

${ }^{\mathrm{ALD}}=$ abaixo do limite de deteç̧ão 
Tabela 6. Análise química das matérias orgânicas utilizadas no ensaio de solarização do solo associada a matérias orgânicas para o controle de Pythium spp. em crisântemo.

\begin{tabular}{lccc}
\hline Matéria Orgânica & Cama-de-frango & Casca de Pinus & Biossólidos \\
\hline $\mathrm{N}(\%)$ & 3,15 & 1,07 & 5,00 \\
$\mathrm{P}\left(\mathrm{P}_{2} \mathrm{O}_{5}\right)(\%)$ & 2,85 & 0,18 & 3,05 \\
$\mathrm{~K}\left(\mathrm{~K}_{2} \mathrm{O}\right)(\mathrm{ppm})$ & 19400 & 1100 & 760 \\
$\mathrm{Ca}(\mathrm{ppm})$ & 14800 & 500 & 12500 \\
$\mathrm{Mg}(\mathrm{ppm})$ & 5000 & 660 & 2300 \\
$\mathrm{~S}(\mathrm{ppm})$ & 10000 & 3600 & 320000 \\
$\mathrm{Fe}(\mathrm{ppm})$ & 1100 & 975 & 38500 \\
$\mathrm{Mn}(\mathrm{ppm})$ & 470 & 160 & 295 \\
$\mathrm{Cu}(\mathrm{ppm})$ & 99 & 38 & 245 \\
$\mathrm{Zn}(\mathrm{ppm})$ & 405 & 45 & 1000 \\
$\mathrm{~B}(\mathrm{ppm})$ & 110 & 550 & 310 \\
$\mathrm{Na}(\mathrm{ppm})$ & 2800 & 340 & 440 \\
Matéria orgânica (\%) & 83,45 & 93 & 64,60 \\
Cinzas (\%) & 16,55 & 7 & 35,40 \\
Umidade (\%) & 23,65 & 61,12 & 81,45 \\
pH & 6,5 & 5,4 & 6,10 \\
Relação C/N & $15 / 1$ & $50 / 1$ & $7 / 1$ \\
\hline & & & \\
\hline
\end{tabular}

\subsubsection{Temperatura do solo}

A solarização promoveu um significativo aumento na temperatura do solo a 10 $\mathrm{cm}$ de profundidade, especialmente durante a segunda quinzena de solarização (Tabela 7). $\mathrm{O}$ aumento de temperatura foi de pelo menos $10^{\circ} \mathrm{C}$, em relação aos tratamentos não 
solarizados. Esses dados estão de acordo com Ghini et al. (1994), que verificaram que o melhor período para a solarização é de setembro a março, para a região de Campinas, SP.

As maiores temperaturas máximas, absoluta e média, foram observadas no solo solarizado com adição de cama-de-frango. As demais matérias orgânicas não proporcionaram tais incrementos de temperatura (Tabela 7).

Tabela 7. Número de horas em que as temperaturas do solo superaram 36,38 e $40^{\circ} \mathrm{C}$, durante a primeira quinzena de solarização (de 12 a 24 fevereiro) e a segunda quinzena ( 3 a 17 de março de 1999) de solarização, na profundidade de $10 \mathrm{~cm}$.

\begin{tabular}{|c|c|c|c|c|c|c|c|c|}
\hline \multirow[t]{2}{*}{ Tratamento } & \multicolumn{2}{|c|}{$>36^{\circ} \mathrm{C}$} & \multicolumn{2}{|c|}{$>38^{\circ} \mathrm{C}$} & \multicolumn{2}{|c|}{$>40^{\circ} \mathrm{C}$} & \multicolumn{2}{|c|}{ Temperatura máxima $\left({ }^{\circ} \mathrm{C}\right)$} \\
\hline & lquinz & 2quinz & lquinz & 2quinz & 1quinz & 2 quinz & Absoluta & Média \\
\hline Test. não solar.* & 7 & 0 & 1 & 0 & 0 & 0 & 38,2 & 31,9 \\
\hline Test. solar. & 131 & 156 & 92 & 116 & 58 & 88 & 48,3 & 43,1 \\
\hline Bioss. não solar. & 8 & 8 & 0 & 0 & 0 & 0 & 37,6 & 33,2 \\
\hline Bioss. solar. & 142 & 180 & 107 & 132 & 80 & 104 & 49,5 & 44,3 \\
\hline C.F. não solar. & 11 & 1 & 1 & 0 & 0 & 0 & 38,2 & 32,7 \\
\hline C.F. solar. & 134 & 193 & 99 & 148 & 66 & 120 & 51,4 & 46,2 \\
\hline C.P. não solar. & 11 & 10 & 1 & 0 & 0 & 0 & 38,2 & 33,4 \\
\hline C.P. solar. & 146 & 180 & 99 & 129 & 69 & 106 & 48,3 & 44,2 \\
\hline
\end{tabular}

*Test. $=$ testemunha; solar. $=$ solarizada; bioss. $=$ biossólidos; C. F. = cama-de-frango;

C. P. = casca de Pinus.

\subsubsection{Avaliação da umidade}

A umidade inicial do solo, antes dos tratamentos foi de $17,55 \%$. Na avaliação realizada durante a solarização (15 dias após a incorporação da matéria orgânica), haviam poucas diferenças entre os tratamentos (Tabela 8). Porém, ao final da solarização (35 dias), nota-se que os tratamentos solarizados apresentaram maiores teores de umidade do que os não solarizados. Com o decorrer do ciclo da cultura, devido à 
realização de constantes irrigações, os tratamentos apresentaram valores semelhantes de umidade.

Tabela 8. Umidade (\%) dos solos dos diferentes tratamentos, 15, 35, 91 e 138 dias após a incorporação da matéria orgânica.

\begin{tabular}{lccccc}
\hline Tratamentos & Solarização & 15 dias & 35 dias & 91 dias & 138 dias \\
\hline Testemunha & não solar & 21,99 & 16,38 & 21,89 & 15,06 \\
Biossólidos & não solar & 21,84 & 16,23 & 20,62 & 13,41 \\
C.-de-frango & não solar & 22,09 & 16,72 & 21,34 & 15,00 \\
C. de Pinus & não solar & 21,19 & 16,22 & 22,11 & 14,53 \\
Testemunha & solar & 19,67 & 19,76 & 21,21 & 14,89 \\
Biossólido & solar & 21,37 & 19,71 & 21,01 & 14,64 \\
C.-de-frango & solar & 19,9 & 18,8 & 21,42 & 14,83 \\
C. de Pinus & solar & 20,9 & 20,13 & 21,38 & 14,65 \\
\hline
\end{tabular}

\subsubsection{Avaliação do $\mathrm{pH}$ e condutividade elétrica dos solos}

Amostras de solo coletadas nos diferentes tratamentos foram analisadas para determinar o $\mathrm{pH}$ e a condutividade elétrica no decorrer do experimento de campo. Nas tabela 9 e 10 estão apresentados os resultados das análises nos diferentes períodos, respectivamente. Antes do início do experimento ( 0 dias) e no final (138 dias), os tratamentos não apresentaram diferenças significativas, quanto às duas variáveis avaliadas. Aos 15 dias, a avaliação de $\mathrm{pH}$ apresentou uma interação significativa entre os fatores solarização e matéria orgânica, sendo que os tratamentos com biossólido e camade-frango nos solos não solarizados diferiram significativamente dos tratamentos com casca de Pinus e testemunha. Nessa mesma data, nos solos que receberam cama-defrango, observou-se uma maior redução de $\mathrm{pH}$ no tratamento não solarizado do que no solarizado (Tabela 9).

Em todas as avaliações realizadas quanto à condutividade elétrica, nota-se que os solos que receberam a incorporação de casca de Pinus não diferiram da testemunha 
(Tabela 10). Os solos solarizados aos 15 e 35 dias apresentaram maior condutividade do que os não solarizados.

Tabela 9. $\mathrm{pH}$ dos solos em diferentes períodos de avaliação durante ensaio de solarização do solo associada a matérias orgânicas para o controle de Pythium spp. em crisântemo.

\begin{tabular}{|c|c|c|c|c|c|c|}
\hline \multirow[t]{2}{*}{ Período } & \multirow[t]{2}{*}{ Tratamentos } & \multicolumn{4}{|c|}{ Matérias orgânicas } & \multirow[t]{2}{*}{ Médias } \\
\hline & & Biossólido & $\begin{array}{c}\text { Cama-de- } \\
\text { frango }\end{array}$ & $\begin{array}{c}\text { Casca de } \\
\text { Pinus }\end{array}$ & Testemunha & \\
\hline \multirow[t]{3}{*}{0 dias } & Não solarizado & 7,23 & 7,21 & 7,14 & 7,19 & 7,19 \\
\hline & Solarizado & 7,20 & 7,20 & 7,16 & 7,25 & 7,20 \\
\hline & Médias & 7,21 & $7,20^{\circ}$ & 7,15 & 7,22 & \\
\hline \multirow[t]{3}{*}{15 dias } & Não solarizado & $6,90 \mathrm{aB}$ & $6,91 \mathrm{bB}$ & $7,23 \mathrm{aA}$ & $7,50 \mathrm{aA}$ & 7,13 \\
\hline & Solarizado & $7,14 \mathrm{aA}$ & $7,21 \mathrm{aA}$ & $7,19 \mathrm{aA}$ & $7,27 \mathrm{aA}$ & 7,20 \\
\hline & Médias & 7,02 & 7,06 & 7,21 & 7,39 & \\
\hline \multirow[t]{3}{*}{35 dias } & Não solarizado & 6,87 & 6,96 & 6,99 & 7,17 & $7,00 \mathrm{a}$ \\
\hline & Solarizado & 6,83 & 6,91 & 6,86 & 7,01 & $6,90 \mathrm{~b}$ \\
\hline & Médias & $6,85 \mathrm{C}^{-}$ & $6,93 \mathrm{~B}$ & $6,92 \mathrm{~B}$ & $7,09 \mathrm{~A}$ & \\
\hline \multirow[t]{3}{*}{91 dias } & Não solarizado & 7,18 & 7,13 & 7,21 & 7,30 & $7,20 \mathrm{a}$ \\
\hline & Solarizado & 7,18 & 7,11 & 7,20 & 7,36 & $7,21 \mathrm{a}$ \\
\hline & Médias & $7,18 \mathrm{~B}$ & $7,12 \mathrm{~B}$ & $7,20 \mathrm{AB}$ & $7,33 \mathrm{~A}$ & \\
\hline \multirow[t]{3}{*}{138 dias } & Não solarizado & 7,33 & 7,33 & 7,41 & 7,43 & $7,37 \mathrm{a}$ \\
\hline & Solarizado & 7,29 & 7,36 & 7,38 & 7,48 & $7,38 \mathrm{a}$ \\
\hline & Médias & $7,31 \mathrm{~A}$ & $7,35 \mathrm{~A}$ & $7,39 \mathrm{~A}$ & $7,45 \mathrm{~A}$ & \\
\hline
\end{tabular}

Dentro de cada período de avaliação, médias seguidas de mesma letra minúscula nas colunas e de mesma letra maiúscula nas linhas não diferem entre si pelo teste Tukey ao nível de 0,05 de probabilidade. 
Tabela 10. Condutividade elétrica $\left(\mathrm{mS}^{\mathrm{c}} \mathrm{cm}^{-1}\right)$ dos solos em diferentes períodos de avaliação durante ensaio de solarização do solo associada a matérias orgânicas para o controle de Pythium spp. em crisântemo.

Período Tratamentos

Matérias orgânicas

Médias

\begin{tabular}{|c|c|c|c|c|c|c|}
\hline & & & & & & \\
\hline & & Biossólido & $\begin{array}{l}\text { Cama-de- } \\
\text { frango }\end{array}$ & $\begin{array}{c}\text { Casca de } \\
\text { Pinus }\end{array}$ & Testemunha & \\
\hline \multirow[t]{3}{*}{0 dias } & Não solarizado & 0,80 & 0,80 & 0,80 & 0,80 & 0,80 \\
\hline & Solarizado & 0,80 & 0,80 & 0,80 & 0,80 & 0,80 \\
\hline & Médias & 0,80 & $0,80^{\circ}$ & $0,80^{\circ}$ & 0,80 & \\
\hline \multirow[t]{3}{*}{15 dias $^{1}$} & Não solarizado & 0,15 & 0,19 & 0,09 & 0,09 & $0,13 \mathrm{~b}$ \\
\hline & Solarizado & 0,19 & 0,30 & 0,11 & 0,11 & $0,18 \mathrm{a}$ \\
\hline & Médias & $0,17 \mathrm{~B}$ & $0,25 \mathrm{~A}$ & $0,10 \mathrm{C}$ & $0,10 \mathrm{C}^{-}$ & \\
\hline \multirow[t]{3}{*}{35 dias $^{2}$} & Não solarizado & $0,15 \mathrm{aB}$ & $0,16 \mathrm{aB}$ & $0,09 \mathrm{aA}$ & $0,08 \mathrm{aA}$ & 0,12 \\
\hline & Solarizado & $0,36 \mathrm{bB}$ & $0,59 \mathrm{bC}$ & $0,18 \mathrm{bA}$ & $0,19 \mathrm{bA}$ & 0,33 \\
\hline & Médias & 0,25 & 0,37 & 0,13 & 0,13 & \\
\hline \multirow[t]{3}{*}{91 dias } & Não solarizado & 0,11 & 0,12 & 0,10 & 0,10 & 0,11 \\
\hline & Solarizado & 0,11 & 0,12 & 0,09 & 0,09 & 0,10 \\
\hline & Médias & $0,11 \mathrm{~A}$ & $0,12 \mathrm{~A}$ & $0,09 \mathrm{~B}$ & $0,09 \mathrm{~B}$ & \\
\hline \multirow[t]{3}{*}{138 dias } & Não solarizado & 0,11 & 0,10 & 0,10 & 0,10 & 0,10 \\
\hline & Solarizado & 0,11 & 0,11 & 0,10 & 0,10 & 0,10 \\
\hline & Médias & 0,11 & 0,10 & 0,10 & $0,10^{\circ}$ & \\
\hline
\end{tabular}

Dentro de cada período de avaliação, médias seguidas de mesma letra minúscula nas colunas e de mesma letra maiúscula nas linhas não diferem entre si pelo teste Tukey ao nível de 0,05 de probabilidade.

${ }^{1}$ Para análise estatística os dados foram transformados em: $\mathrm{x}^{-2}$

${ }^{2}$ Para análise estatística os dados foram transformados em: $\log \mathrm{x}$ 


\subsubsection{Atividade microbiana do solo}

De modo geral, a atividade microbiana do solo, avaliada aos 15 e 35 dias de solarização por meio da hidrólise de diacetato de fluoresceina, foi maior com a incorporação de cama-de-frango, do que com as demais fontes de matéria orgânica (Tabela 11). Esse fato demonstra a fácil degradabilidade da matéria orgânica da camade-frango. A casca de Pinus reduziu a atividade microbiana do solo, avaliada pela hidrólise de FDA, dos 15 aos 91 dias, voltando a aumentar depois desse período, possivelmente devido à presença de fenóis que inibem o desenvolvimento de microrganismos.

Dentre as matérias orgânicas, a cama-de-frango em solo solarizado foi a que proporcionou maior desprendimento de $\mathrm{CO}_{2}$, nos 35 primeiros dias (Tabela 12). Isso foi motivado pelo alto teor de matéria orgânica da cama-de-frango e pela relação $\mathrm{C} / \mathrm{N}$ (Tabela 6), porque havia matéria orgânica decomponível e nitrogênio suficiente para a sua decomposição. Entre os 91 e 138 dias, verifica-se uma redução no desprendimento de $\mathrm{CO}_{2}$ do solo tratado com cama-de-frango. Justamente nesse período, ocorreu um aumento de desprendimento de $\mathrm{CO}_{2}$ no solo onde a casca de Pinus foi incorporada, pois possivelmente houve uma redução na relação $\mathrm{C} / \mathrm{N}$, haja vista que a matéria orgânica da casca de Pinus é de lenta decomposição. $\mathrm{O}$ biossólido teve desprendimento de $\mathrm{CO}_{2}$ semelhante à testemunha (Tabela 12) porque, dentre os materiais estudados, foi o que apresentou menor teor de matéria orgânica e maior teor de cinzas (Tabela 6). 
Tabela 11. Atividade microbiana do solo, avaliada pela hidrólise de diacetato de fluoresceina ( $\mu \mathrm{g}$ FDA hidrolisado/g solo seco), em diferentes períodos de avaliação durante ensaio de solarização do solo associada a matérias orgânicas para o controle de Pythium spp. em crisântemo.

\begin{tabular}{|c|c|c|c|c|c|c|}
\hline \multirow[t]{2}{*}{ Período } & \multirow[t]{2}{*}{ Tratamentos } & \multicolumn{4}{|c|}{ Matérias orgânicas } & \multirow[t]{2}{*}{ Médias } \\
\hline & & Biossólido & $\begin{array}{l}\text { Cama-de- } \\
\text { frango }\end{array}$ & $\begin{array}{c}\text { Casca de } \\
\text { Pinus }\end{array}$ & Testemunha & \\
\hline \multirow[t]{3}{*}{0 dias } & Não solarizado & 17,30 & 20,74 & 22,45 & 18,24 & 19,68 \\
\hline & Solarizado & 19,20 & 20,97 & 18,19 & 19,56 & 19,48 \\
\hline & Médias & $18,25^{\circ}$ & 20,86 & 20,32 & $18,90^{\circ}$ & \\
\hline \multirow[t]{3}{*}{$15 \operatorname{dias}^{1}$} & Não solarizado & 20,02 & 31,25 & 10,88 & 8,47 & 17,66 \\
\hline & Solarizado & 21,48 & 33,13 & 6,21 & 6,86 & 16,92 \\
\hline & Médias & $20,75 \mathrm{~B}$ & $32,19 \mathrm{~A}$ & $8,55 \mathrm{C}$ & $7,66 \mathrm{C}$ & \\
\hline \multirow[t]{3}{*}{35 dias } & Não solarizado & 14,14 & 20,56 & 14,59 & 10,42 & $14,93 \mathrm{a}$ \\
\hline & Solarizado & 11,70 & 16,34 & 7,28 & 10,90 & $11,56 \mathrm{~b}$ \\
\hline & Médias & $12,92 \mathrm{~B}$ & $18,45 \mathrm{~A}$ & $10,93 \mathrm{C}$ & $10,66 \mathrm{C}^{-\cdots}$ & \\
\hline \multirow[t]{3}{*}{91 dias } & Não solarizado & 10,41 & 11,14 & 11,04 & 10,08 & 10,67 \\
\hline & Solarizado & 12,32 & 12,90 & 6,08 & 9,61 & 10,22 \\
\hline & Médias & 11,36 & 12,02 & 8,56 & 9,84 & \\
\hline \multirow[t]{3}{*}{138 dias } & Não solarizado & 13,38 & 18,68 & 15,55 & 13,28 & $15,22 \mathrm{a}$ \\
\hline & Solarizado & 10,68 & 14,40 & 14,93 & 13,13 & $13,29 \mathrm{~b}$ \\
\hline & Médias & $12,03 \mathrm{~B}$ & $16,54 \mathrm{~A}$ & $15,24 \mathrm{~A}$ & $13,21 \mathrm{~B}$ & \\
\hline
\end{tabular}

Dentro de cada período de avaliação, médias seguidas de mesma letra minúscula nas colunas e de mesma letra maiúscula nas linhas não diferem entre si pelo teste Tukey ao nível de 0,05 de probabilidade.

${ }^{1}$ Para análise estatística os dados foram transformados em: $\log \mathrm{x}$ 
Tabela 12. Atividade microbiana do solo, avaliada pelo desprendimento de $\mathrm{CO}_{2}(\mathrm{mg}$ $\mathrm{CO}_{2} / \mathrm{g}$ solo seco), em diferentes períodos de avaliação durante ensaio de solarização do solo associada a matérias orgânicas para o controle de Pythium spp. em crisântemo.

\begin{tabular}{|c|c|c|c|c|c|c|}
\hline \multirow[t]{2}{*}{ Período } & \multirow[t]{2}{*}{ Tratamentos } & \multicolumn{4}{|c|}{ Matérias orgânicas } & \multirow[t]{2}{*}{ Médias } \\
\hline & & Biossólido & $\begin{array}{l}\text { Cama-de- } \\
\text { frango }\end{array}$ & $\begin{array}{c}\text { Casca de } \\
\text { Pinus }\end{array}$ & Testemunha & \\
\hline \multirow[t]{3}{*}{15 dias $^{1}$} & Não solarizado & $0,47 \quad \mathrm{aB}$ & 0,90 aA & $0,69 \quad \mathrm{bB}$ & $0,25 \mathrm{bC}$ & 0,58 \\
\hline & Solarizado & $0,44 \mathrm{aB}$ & $1,12 \mathrm{aA}$ & $0,29 \mathrm{aC}$ & $0,19 \mathrm{aD}$ & 0,51 \\
\hline & Médias & 0,46 & 1,01 & 0,49 & 0,22 & \\
\hline \multirow[t]{3}{*}{$35 \operatorname{dias}^{1}$} & Não solarizado & $0,27 \mathrm{aA}$ & $0,32 \mathrm{bA}$ & $0,30 \mathrm{aA}$ & $0,21 \mathrm{aB}$ & 0,27 \\
\hline & Solarizado & $0,31 \mathrm{aB}$ & $0,68 \mathrm{aA}$ & $0,26 \mathrm{aBC}$ & $0,21 \mathrm{aC}$ & 0,37 \\
\hline & Médias & 0,29 & $0,50^{\circ}$ & 0,28 & 0,21 & \\
\hline \multirow[t]{3}{*}{91 dias } & Não solarizado & 0,33 & 0,42 & 0,48 & 0,37 & 0,40 \\
\hline & Solarizado & 0,36 & 0,42 & 0,47 & 0,31 & 0,39 \\
\hline & Médias & $0,34 \mathrm{C}$ & $0,42 \mathrm{~B}$ & $0,48 \mathrm{~A}$ & $0,34 \mathrm{C}^{-\cdots}$ & \\
\hline \multirow[t]{3}{*}{$138 \operatorname{dias}^{2}$} & Não solarizado & 0,27 & 0,34 & 0,49 & 0,30 & 0,35 \\
\hline & Solarizado & 0,28 & 0,34 & 0,30 & 0,28 & 0,30 \\
\hline & Médias & $0,28 \mathrm{~B}$ & $0,34 \mathrm{AB}$ & $0,40 \mathrm{~A}$ & $0,29 \mathrm{~B}$ & \\
\hline
\end{tabular}

Dentro de cada periodo de avaliação, médias seguidas de mesma letra minúscula nas colunas e de mesma letra maiúscula nas linhas não diferem entre si pelo teste Tukey ao nível de 0,05 de probabilidade.

${ }^{1}$ Para análise estatística os dados foram transformados em: $\mathrm{x}^{-2}$.

${ }^{2}$ Para análise estatística os dados foram transformados em: $1 / x$ 


\subsubsection{Avaliação de plantas daninhas}

Logo após a retirada do plástico utilizado na solarização, foi observado que as parcelas solarizadas não apresentaram plantas daninhas (Tabela 13), indicando que as temperaturas foram suficientes para a sua eliminação. Esses dados estão de acordo com os apresentados por Bettiol et al. (1994), em trabalho realizado com solarização para o controle de Pythium e plantas daninhas, também no Município de Holambra, SP.

Tabela 13. Efeito de fontes de matéria orgânica e da solarização no peso de matéria fresca e seca de plantas daninhas $\left(\mathrm{g} / \mathrm{m}^{2}\right)$.

\begin{tabular}{lccc}
\hline Matéria orgânica & Solarização . & $\begin{array}{c}\text { Matéria fresca } \\
\left(\mathrm{g} / \mathrm{m}^{2}\right)\end{array}$ & $\begin{array}{c}\text { Matéria seca } \\
\left(\mathrm{g} / \mathrm{m}^{2}\right)\end{array}$ \\
\hline Testemunha & não solarizado & 119,04 & 34,62 \\
Biossólido & não solarizado & 194,23 & 52,32 \\
Cama-de-frango & não solarizado & 172,84 & 44,71 \\
Casca de Pinus & não solarizado & 133,95 & 31,92 \\
Testemunha & solarizado & 0 & 0 \\
Biossólido & solarizado & 0 & 0 \\
Cama-de-frango & solarizado & 0 & 0 \\
Casca de Pinus & solarizado & 0 & 0 \\
\hline
\end{tabular}




\subsubsection{Avaliação da resistência à penetração}

A avaliação da resistência à penetração mostrou que os solos solarizados não diferiram dos não solarizados quanto a essa variável (Tabela 14). Porém, o biossólido e a casca de Pinus aumentaram a resistência à penetração dos solos, em relação aos demais tratamentos. Esses dados confirmam as observações de Souza ${ }^{1}$, que verificou resultados semelhantes em estudo sobre o efeito de biossólidos nas propriedades físicas do solo.

Tabela 14. Efeito de fontes de matéria orgânica e da solarização na resistência a penetração no solo $\left(\mathrm{kgf} / \mathrm{cm}^{2}\right)$.

\begin{tabular}{lccccc}
\hline \multirow{2}{*}{ Tratamentos } & \multicolumn{5}{c}{ Matéria orgânica } \\
\cline { 2 - 6 } & Biossólido & $\begin{array}{c}\text { Cama-de- } \\
\text { frango }\end{array}$ & $\begin{array}{c}\text { Casca de } \\
\text { Pinus }\end{array}$ & Testemunha & Médias \\
\hline Não solarizado & 0,86 & 0,48 & 1,04 & 0,45 & 0,71 \\
Solarizado & 1,52 & 0,28 & 0,98 & 0,35 & 0,78 \\
\hline Médias & $1,19 \mathrm{~A}$ & $0,38 \mathrm{~B}$ & $1,01 \mathrm{~A}$ & $0,40 \mathrm{~B}$ &
\end{tabular}

Médias seguidas pela mesma letra não diferem entre si pelo teste Tukey ao nível de 0,05 de probabilidade.

\subsubsection{Controle do patógeno}

Como não houve a ocorrência de Pythium na cultura de crisântemo, foi utilizado o método de Lourd et al. (1986), onde plântulas de pepino atuam como indicadoras da presença do patógeno nos solos. Na Tabela 15 estão os resultados de porcentagem de plântulas de pepino que apresentaram tombamento nos diferentes tratamentos após 15, 35, 91 e 138 dias da incorporação das matérias orgânicas. Nota-se que a incorporação de cama-de-frango controlou significativamente o patógeno em todos os períodos avaliados.

\footnotetext{
${ }^{1}$ Souza Junior, M. D. de A. (Embrapa Meio Ambiente, Jaguariúna, SP). Comunicação pessoal, 2001.
} 
Tabela 15. Efeito de fontes de matéria orgânica e da solarização na sobrevivência de Pythium spp. avaliada pelo tombamento de mudas de pepino (\%) em diferentes períodos de avaliação.

\begin{tabular}{|c|c|c|c|c|c|c|}
\hline \multirow[t]{2}{*}{ Período } & \multirow[t]{2}{*}{ Tratamentos } & \multicolumn{4}{|c|}{ Matérias orgânicas } & \multirow[t]{2}{*}{ Médias } \\
\hline & & Biossólido & $\begin{array}{l}\text { Cama-de- } \\
\text { frango }\end{array}$ & $\begin{array}{c}\text { Casca de } \\
\text { Pinus }\end{array}$ & Testemunha & \\
\hline \multirow[t]{3}{*}{15 dias } & Não solarizado & 100,00 & 73,16 & 96,16 & 99,16 & 92,12 \\
\hline & Solarizado & 93,36 & 29,16 & 98,96 & 98,23 & 79,93 \\
\hline & Médias & $96,68 \mathrm{~A}$ & $51,16 \mathrm{~B}$ & $97,56 \mathrm{~A}$ & $98,70 \mathrm{~A}$ & \\
\hline \multirow[t]{3}{*}{$35 \operatorname{dias}^{1}$} & Não solarizado & 100,00 & 58,40 & 98,96 & 100,00 & 89,34 \\
\hline & Solarizado & 100,00 & 71,50 & 100,00 & 98,20 & 92,42 \\
\hline & Médias & $100,00 \mathrm{~A}$ & $64,95 \mathrm{~B}$ & $99,48 \mathrm{~A}$ & $99,10 \mathrm{~A}$ & \\
\hline \multirow[t]{3}{*}{91 dias $^{2}$} & Não solarizado & 45,43 & 27,96 & 16,66 & 37,03 & 31,77 \\
\hline & Solarizado & 34,23 & 29,16 & 33,33 & 20,00 & 29,18 \\
\hline & Médias & $39,83^{-}$ & 28,56 & 25,00 & 28,51 & \\
\hline \multirow[t]{3}{*}{138 dias } & Não solarizado & 73,86 & 41,90 & 58,23 & 81,50 & 63,87 \\
\hline & Solarizado & 45,63 & 36,56 & 50,06 & 77,00 & 52,31 \\
\hline & Médias & $59,75 \mathrm{AB}$ & $39,23 \mathrm{C}$ & $54,15 \mathrm{BC}$ & $79,25 \mathrm{~A}$ & \\
\hline
\end{tabular}

Dentro de cada período de avaliação, médias seguidas de mesma letra não diferem entre si pelo teste Tukey ao nível de 0,05 de probabilidade.

${ }^{1}$ Para análise estatística os dados foram transformados em: $x^{7,2}$.

${ }^{2}$ Para análise estatística os dados foram transformados em: $(x+1)^{-0,1}$.

A baixa porcentagem de tombamento de plântulas aos 91 dias foi devido às condições climáticas desfavoráveis ao patógeno, que resultou na ausência de diferenças significativas entre os tratamentos. 
A correlação entre as variáveis avaliadas no ensaio, aos 15 dias, demontrou que a condutividade elétrica e a atividade microbiana do solo (avaliada pelo desprendimento de $\mathrm{CO}_{2}$ e hidrólise de FDA) apresentam correlação positiva entre si e negativa com o tombamento de plântulas de pepino (Tabela 16). $\mathrm{O}$ pH não apresentou correlação com as demais variáveis. Ghini et al. (1998) também verificaram por meio de análise de regressão, que o crescimento micelial de $R$. solani foi negativamente correlacionado com os dois métodos utilizados para avaliação da atividade microbiana (atividade respiratória e hidrólise de FDA) e com o teor de matéria orgânica dos solos.

No presente trabalho, a incorporação de cama-de-frango ao solo resultou em maiores temperaturas no solo solarizado (Tabela 7), maiores aumentos na condutividade elétrica (Tabela 10), maior atividade microbiana do solo (Tabelas 11 e 12), menor resistência à penetração no solo (Tabela 14), além de controle do patógeno (Tabelas 2, 3, 4).

\subsubsection{Altura de plantas de crisântemo e peso do sistema radicular}

De modo geral, em solos solarizados se observa um maior desenvolvimento de plantas (Katan \& DeVay, 1991). Porém, no ensaio de campo com crisântemo, os tratamentos não diferiram quanto à altura de plantas e peso do sistema radicular (Tabela 17 e 18, respectivamente), nem nas avaliações quanto à qualidade de flores e produtividade nos diferentes tratamentos. Provavelmente, esse fato se deve à não ocorrência da doença e à intensa fertilização que a cultura recebe durante o ciclo, eliminando as possíveis diferenças entre os tratamentos. 
Tabela 16. Correlação linear simples entre as variáveis avaliadas no ensaio de solarização associada a matérias orgânicas para o controle de Pythium spp. em crisântemo, aos 15 dias após a incorporação das matérias orgânicas ao solo.

\begin{tabular}{|c|c|c|c|c|c|}
\hline & $\mathrm{pH}$ & $\begin{array}{c}\text { Condutividade } \\
\text { elétrica }\end{array}$ & $\begin{array}{l}\text { Hidrólise de } \\
\text { FDA }\end{array}$ & $\begin{array}{c}\text { Desprendime } \\
\text { nto de } \mathrm{CO}_{2}\end{array}$ & $\begin{array}{c}\text { Tombamento } \\
\text { de plântulas } \\
\text { de pepino }\end{array}$ \\
\hline $\mathrm{pH}$ & - & $-0,2391 \mathrm{~ns}$ & $-0,3678 \mathrm{~ns}$ & $-0,2601 \mathrm{~ns}$ & $0,1612 \mathrm{~ns}$ \\
\hline $\begin{array}{l}\text { Condutividade } \\
\text { elétrica }\end{array}$ & & - & $0,8591^{* *}$ & $0,7495^{* *}$ & $-0,8063^{* *}$ \\
\hline $\begin{array}{l}\text { Hidrólise de } \\
\text { FDA }\end{array}$ & & & - & $0,7924^{* *}$ & $-0,7314^{* *}$ \\
\hline $\begin{array}{l}\text { Desprendimento } \\
\text { de } \mathrm{CO}_{2}\end{array}$ & & & & - & $-0,7443^{* *}$ \\
\hline $\begin{array}{l}\text { Tombamento de } \\
\text { plântulas de } \\
\text { pepino }\end{array}$ & & & & & - \\
\hline
\end{tabular}

Significativo a $1 \%$ de probabilidade pelo teste $\mathfrak{t}$; $\mathrm{ns}=$ não significativo.

Tabela 17. Efeito de fontes de matéria orgânica e da solarização na altura de plantas de crisântemo $(\mathrm{cm})$.

\begin{tabular}{lccccc}
\hline \multirow{2}{*}{ Tratamentos } & \multicolumn{5}{c}{ Matéria orgânica } \\
\cline { 2 - 6 } & Biossólido & $\begin{array}{c}\text { Cama-de- } \\
\text { frango }\end{array}$ & $\begin{array}{c}\text { Casca de } \\
\text { Pinus }\end{array}$ & Testemunha & Médias \\
\hline Não solarizado & 110,00 & 114,63 & 112,53 & 108,53 & $111,33 \mathrm{a}$ \\
Solarizado & 113,66 & 116,53 & 110,63 & 113,60 & $113,60 \mathrm{a}$ \\
\hline Médias & $111,83 \mathrm{~A}$ & $115,58 \mathrm{~A}$ & $111,40 \mathrm{~A}$ & $111,06 \mathrm{~A}$ \\
\hline $\begin{array}{l}\text { Médias seguidas pela mesma letra não diferem entre si pelo teste Tukey ao nível de } 0,05 \\
\text { de probabilidade. }\end{array}$
\end{tabular}


Tabela 18. Efeito de fontes de matéria orgânica e da solarização no peso de raízes de plantas de crisântemo ( $\mathrm{g} /$ planta).

\begin{tabular}{lccccc}
\hline \multirow{2}{*}{ Tratamentos } & \multicolumn{5}{c}{ Matéria orgânica } \\
\cline { 2 - 6 } & Biossólido & $\begin{array}{c}\text { Cama-de- } \\
\text { frango }\end{array}$ & Casca de & Pinus & \\
\hline Não solarizado & 4,32 & 5,26 & 4,72 & 5,23 & 4,88 a \\
Solarizado & 5,03 & 5,39 & 4,55 & 5,47 & 5,11 a \\
\hline Médias & $4,67 \mathrm{~A}$ & $5,33 \mathrm{~A}$ & $4,63 \mathrm{~A}$ & $5,35 \mathrm{~A}$ \\
\hline $\begin{array}{l}\text { Médias seguidas pela mesma letra não diferem entre si pelo teste Tukey ao nível de } 0,05 \\
\text { de probabilidade. }\end{array}$
\end{tabular}

\subsubsection{Solarização do solo associada a matérias orgânicas para o controle de Pythium spp em pepino}

Os solos solarizados apresentaram maiores teores de umidade do que os tratamentos não solarizados, logo após a retirada do plástico (Tabela 19), de forma semelhante ao que ocorreu no ensaio com crisântemo (Tabela 8).

A avaliação da atividade microbiana do solo indicou que os tratamentos solarizados apresentaram menor hidrólise de FDA e maior desprendimento de $\mathrm{CO}_{2}$ do que os não solarizados (Tabelas 20 e 21). Nos dois métodos utilizados, a adição de cama-de-frango promoveu um aumento na atividade microbiana do solo.

Os tratamentos solarizados e não solarizados diferiram significativamente quanto ao controle e recuperação de Pythium spp. (Tabelas 22 e 23, respectivamente). Esses resultados estão de acordo com os obtidos por Bettiol et al. (1994), onde a solarização foi um eficiente método de controle do patógeno. Quanto às matérias orgânicas, foram poucas as diferenças observadas entre os tratamentos. 
Tabela 19. Efeito de fontes de matéria orgânica e da solarização na umidade do solo, após término da solarização, no ensaio de solarização do solo associada a matérias orgânicas para o controle de Pythium spp. em pepino.

\begin{tabular}{llc}
\hline Matéria orgância & Solarização & Umidade (\%) \\
\hline Testemunha & não solarizado & 5,35 \\
Biossólido & não solarizado & 6,02 \\
Cama-de-frango & não solarizado & 5,37 \\
Casca de Pinus & não solarizado & 7,02 \\
Testemunha & Solarizado & 12,86 \\
Biossólido & Solarizado & 10,64 \\
Cama-de-frango & Solarizado & 12,49 \\
Casca de Pinus & Solarizado & 13,23 \\
\hline
\end{tabular}

Tabela 20. Atividade microbiana do solo, avaliada pela hidrólise de diacetato de fluoresceina ( $\mu \mathrm{g}$ FDA hidrolisado/g solo seco) durante ensaio de solarização do solo associada a matérias orgânicas para o controle de Pythium spp. em pepino.

\begin{tabular}{lccccc}
\hline \multirow{2}{*}{ Tratamentos } & \multicolumn{5}{c}{ Matéria orgânica } \\
\cline { 2 - 6 } & Biossólido & $\begin{array}{c}\text { Cama-de- } \\
\text { frango }\end{array}$ & $\begin{array}{c}\text { Casca de } \\
\text { Pinus }\end{array}$ & Testemunha & Médias \\
\hline Não solarizado & 25,20 & 39,12 & 25,46 & 22,51 & $28,07 \mathrm{a}$ \\
Solarizado & 16,64 & 28,62 & 22,27 & 18,34 & $21,47 \mathrm{~b}$ \\
\hline Médias & $20,92 \mathrm{~B}$ & $33,87 \mathrm{~A}$ & $23,86 \mathrm{~B}$ & $20,43 \mathrm{~B}$ \\
\hline $\begin{array}{l}\text { Médias seguidas pela mesma letra não diferem entre si pelo teste Tukey ao nível de } 0,05 \\
\text { de probabilidade. }\end{array}$
\end{tabular}


Tabela 21. Atividade microbiana do solo, avaliada pelo desprendimento de $\mathrm{CO}_{2}$ (mg $\mathrm{CO}_{2} / \mathrm{g}$ solo seco), durante ensaio de solarização do solo associada a matérias orgânicas para o controle de Pythium spp. em pepino.

\begin{tabular}{lccccc}
\hline \multirow{2}{*}{ Tratamentos } & \multicolumn{5}{c}{ Matéria orgânica } \\
\cline { 2 - 6 } & Biossólido & $\begin{array}{c}\text { Cama-de- } \\
\text { frango }\end{array}$ & $\begin{array}{c}\text { Casca de } \\
\text { Pinus }\end{array}$ & Testemunha & Médias \\
\hline Não solarizado & 0,23 & 0,38 & 0,21 & 0,18 & $0,25 \mathrm{~b}$ \\
Solarizado & 0,38 & 1,05 & 0,39 & 0,38 & $0,55 \mathrm{a}$ \\
\hline Médias & $0,30 \mathrm{~B}$ & $0,71 \mathrm{~A}$ & $0,30 \mathrm{~B}$ & $0,28 \mathrm{~B}$ & \\
\hline
\end{tabular}

Para análise estatística os dados foram transformados em: $\log \mathrm{x}$. Médias seguidas pela mesma letra não diferem entre si pelo teste Tukey ao nível de 0,05 de probabilidade.

Tabela 22. Efeito de fontes de matéria orgânica e da solarização do solo na porcentagem de plantas de pepino sadias em solo infestado com Pythium spp.

\begin{tabular}{lccccc}
\hline \multirow{2}{*}{ Tratamentos } & \multicolumn{5}{c}{ Matéria orgânica } \\
\cline { 2 - 6 } & Biossólido & $\begin{array}{c}\text { Cama-de- } \\
\text { frango }\end{array}$ & $\begin{array}{c}\text { Casca de } \\
\text { Pinus }\end{array}$ & Testemunha & Médias \\
\hline Não solarizado & $4,92 \mathrm{bB}$ & $\mathbf{8 , 7 5} \mathrm{bA}$ & $3,00 \mathrm{bB}$ & $10,08 \mathrm{bA}$ & 6,68 \\
Solarizado & $29,58 \mathrm{aAB}$ & $31,92 \mathrm{aA}$ & $28,92 \mathrm{aAB}$ & $27,25 \mathrm{aB}$ & 29,41 \\
\hline Médias & 17,25 & 20,33 & 15,96 & 18,66 & \\
\hline
\end{tabular}

T'Número médio de plantas sadias em quatro linhas de plantio de pepino/parcela.

Médias de solarização seguidas de mesma letra minúscula (coluna) não diferem entre si e médias de matéria orgânica seguidas de mesma letra maiúscula (linha) não diferem entre si pelo teste ao nivel de 0,05 de probabilidade. Para análise estatística os dados foram transformados em: $x+1$. 
Tabela 23. Efeito de fontes de matéria orgânica e da solarização na recuperação de Pythium spp. com utilização de iscas feitas com cubos de batata.

\begin{tabular}{lccccc}
\hline \multirow{2}{*}{ Tratamentos } & \multicolumn{5}{c}{ Matéria orgânica } \\
\cline { 2 - 6 } & Biossólido & $\begin{array}{c}\text { Cama-de- } \\
\text { frango }\end{array}$ & $\begin{array}{c}\text { Casca de } \\
\text { Pinus }\end{array}$ \\
\hline Não solarizado & $9,00 \mathrm{aAB}{ }^{1}$ & $7,66 \mathrm{aC}$ & $9,22 \mathrm{aA}$ & $9,00 \mathrm{aAB}$ & 8,72 \\
Solarizado & $0,33 \mathrm{bA}$ & $1,33 \mathrm{bA}$ & $1,33 \mathrm{bA}$ & $0,88 \mathrm{bA}$ & 0,97 \\
\hline Médias & 4,66 & 4,50 & 5,27 & 4,94 & Médias \\
\hline Médias de solarização seguidas de mesma letra minúscula (coluna) não diferem entre si \\
e médias de matéria orgânica seguidas de mesma letra maiúscula (linha) não diferem \\
entre si pelo teste Tukey ao nível de 0,05 de probabilidade. \\
'Para a análise estatística, os dados foram transformados em x + 1.
\end{tabular}

\subsection{Identificação de espécies de Pythium spp.}

A identificação de espécies de Pythium foi realizada no decorrer dos experimentos, utilizando isolados escolhidos aleatoriamente.

No ensaio conduzido em casa de vegetação, utilizando solo naturalmente infestado com o patógeno (item 3.1.2), nos tratamentos com biossólido foram obtidos isolados de Pythium ultimum Trow var. ultimum Plaats-Niterink. Nos tratamentos com folhas de repolho e compostos de resíduos de flores, foi observado a presença de Pythium aphanidermatum (Edson) Fitzp. No ensaio realizado com a associação de solarização e matérias orgânicas para o controle de Pythium em pepino, em todos os tratamentos foram obtidos isolados de $P$. aphanidermatum, exceto na testemunha não solarizada, de onde foi isolado Pythium graminicola Subramaniam.

Esses resultados evidenciam a diversidade de espécies de Pythium nos solos da região onde os ensaios foram realizados (Campinas, SP). 


\section{CONCLUSÕES}

A incorporação de folhas de couve-flor promoveu a redução do crescimento micelial de Pythium spp. e do tombamento de plântulas de pepino.

A adição de cama-de-frango ao solo induz supressividade ao patógeno visto que resultou em maiores temperaturas no solo solarizado, aumento na condutividade elétrica, maior atividade microbiana e menor resistência à penetração no solo. Os produtos químicos utilizados na produção de frangos não são os responsáveis pelo controle do patógeno.

A solarização controlou as plantas daninhas, não teve efeito no crescimento de plantas de crisântemo e peso de raízes. A solarização não teve efeito significativo no controle do patógeno no ensaio conduzido com crisântemo, mas teve no ensaio realizado com pepino.

Há uma diversidade de espécie de Pythium nos solos estudados. 


\section{REFERÊNCIAS BIBLIOGRÁFICAS}

ARMITAGE, A.M. Ornamental bedding plants. Wallingford: CAB International, 1994. $175 p$.

BETTIOL, W; KRUGNER, T.L. Influência do lodo de esgoto na severidade da podridão de raíz do sorgo causada por Pyhtium arrhenomanes. Summa Phytopathologica, v.10, p.243-251, 1984.

BETTIOL, W.; GHINI, R.; GALVÃO, J.A.H. Solarização do solo para o controle de Pythium e plantas daninhas em culturas de crisântemo. Scientia Agricola, v.51, n.3, p.459-462, 1994.

BIHAN, B.L.; SOULAS, M.L.; CAMPOROTA, P.; SALERNO, M.I.; PERRIN, R. Evaluation of soil solar heating for control of damping-off fungi in two forest nurseries in France. Biology and Fertility of Soils, v.25, p.189-195, 1997.

BOEHM, M.J.; HOITINK, H.A.J. Suistenance of microbial activity in potting mixes and its impact on severity of Pythium root rot of poinsettia. Phytopathology, v.82, n.3, p.259-264, 1992.

COX, R.W. Control of Pythium wilt of chrysanthemum in south Florida. Plant Disease Reporter, v.53, p.912-913, 1969. 
DAFT, G.C.; POOLE, H.A.; HOITINK, H.A.J. Composted hardwood bark: a substitute for steam sterilization and fungicide drenches for control of poinsettia crown and root rot. HortScience, v.14, n.2, p.185-187, 1979.

GAMLIEL, A.; STAPLETON, J.J. Characterization of antifungal volatile compounds evolved from solarized soil amended with cabbage residues. Phytopathology, v.83, n.9, p. 899-905, 1993a.

GAMLIEL, A.; STAPLETON, J.J. Effect of chicken compost or ammonium phosphate and solarization on pathogen control, rhizosphere microorganisms, and lettuce growth. Plant Disease, v.77, n.9, p.886-891, 1993b.

GHINI, R. Desinfestação do solo com o uso de energia solar: solarização e coletor solar. Jaguariúna: Embrapa, CNPMA, 1997. 29p.

GHINI, R.; MENDES, M.D.L.; BETTIOL, W. Método de hidrólise de diacetato de fluoresceina (FDA) como indicador de atividade microbiana no solo e supressividade a Rhizoctonia solani. Summa Phytopathologica, v.24, n.3/4, p.239-242, 1998.

GHINI, R.; PARAIBA, L.C.; LIMA, M. W. P. Determinação de período para solarização do solo na região de Campinas/SP. Summa Phytopathologica, v.20, n.2, p.131-133, 1994.

GRISI, B.M. Método químico de medição da respiração edáfica: alguns aspectos técnicos. Ciência e Cultura, v.30, n.1, p.82-88, 1978.

HINE, R.B.; LUNA, L.V. Technique for isolating Pythium aphanidermatum from soil. Phytopathology, v.53, p.727-728, 1963. 
HORST, R.K.; NELSON P.E. Compendium of chrysanthemum diseases. St Paul: APS Press, 1997. 62p. (The Disease Compendium Series of the American Phytophatological Society).

IMENES, S.D.L.; ALEXANDRE, M.A.V. Aspectos fitossanitários do crisântemo. São Paulo: Instituto Biológico, 1996. 47p. (Instituto Biológico. Boletim técnico, 5.)

JARVIS, W.R. Managing diseases in greenhouse crops. 2.ed. St. Paul: APS PRESS, 1992. 288p.

KATAN, J.; DEVAY, J.E. Soil solarization. Boca Raton: CRC Press, 1991. 267p.

KATAN, J.; GREENBERGER, A.; ALON, H.; GRINSTEIN, A. Solar heating by polyethylene mulching for the control of diseases caused by soil-borne pathogens. Phytopathology, v.66, p.683-688, 1976.

KIMATI, H.; GIMENES FERNANDES, N.; SOAVE, J.; KUROZAWA, C.; BRIGNANI NETO, F.; BETTIOL, W. Guia de fungicidas agrícolas. 2.ed. Jaboticabal: Grupo Paulista de Fitopatologia, 1997. 225p.

KIRKEGAARD, J.A.; SARWAR, M.; MATTHIESSEN, J.N. Assessing the biofumigation potential of crucifers. Acta Horticulturae, v.459, p. 105-111, 1998.

KUTER, G.A.; HOITINK, H.A.J.; CHEN, W. Effects of municipal sludge compost curing time on suppression of Pythium and Rhizoctonia diseases of ornamental plants. Plant Disease, v.72, p.751-756, 1988.

LEWIS, J.A.; LUMSDEN, R.D.; MILLNER, P.D.; KEINATH, A.P. Supression of damping-off of peas and cotton in the field with composted sewage sludge. Crop Protection, v.11, n.6, p.260-266, 1992. 
LOURD, M.; ALVEZ,M.L.B.; BOUHOUT, D. Análise qualitativa e quantitativa de espécies de Pythium patogênicas dos solos no município de Manaus. Fitopatologia Brasileira, v.11, p.479-485, 1986.

LUMSDEN, R.D.; LEWIS, J.A.; MILLNER, P.D. Effect of composted sewage sludge on several soilborne pathogens and diseases. Phytopathology, v.73, n.11, p.1543$1548,1983$.

MANSOORI , B.; JALIANI, N.KH. Control of soilborne pathogens of watermelon by solar heating. Crop Protection, v. 15, n.5, p.423-424, 1996.

MARTIN, F.N.; HANCOCK, J.G. Association of chemical and biological factors in soils suppresive to Pythium ultimum. Phytopathology, v.79, n.11, p.1221-1231, 1986.

MILLNER, P.D.; LUMSDEN, R.D.; LEWIS, J.A. Controlling plant disease with sludge compost. BioCycle, v.23, n.4, p.50-52, 1982.

NELSON, E.B.; KUTER, G.A.; HOITINK, H.A.J. Effects of fungal antagonists and compost age on suppression of Rhizoctonia damping-off in container media amended with composted hardwood bark. Phytopathology, v.73, p.1457-1462, 1983.

PATRICIO, F.R.A. Solarização do solo em ambiente protegido e sua integração com controle biológico ou químico na viabilidade de Pythium aphanidermatum e Rhizoctonia solani. Piracicaba, 2000. 89p. Tese (Doutorado) Escola Superior de Agricultura "Luiz de Queiroz", Universidade de São Paulo.

PULLMAN, G.S.; DEVAY, J.E.; GARBER, R.H. Soil solarization and thermal death: a logarithmic relationship between time and temperature for four soilborne plant pathogens. Phytopathology, v.71, n.9, p.959-964, 1981. 
RAMIREZ-VILLAPUDUA, J; MUNNECKE, D.E. Effect of solar heating and soil amendments of cruciferous residues on Fusarium oxysporum $\mathrm{f}$. sp. conglutinans and other organisms. Phytopathology, v.78, n.3, p.289-295, 1988.

REIS, E.M. Solos supressivos e seu aproveitamento no controle de doenças de plantas. In: BETTIOL, W. Controle biológico de doenças de plantas. Jaguariúna: Embrapa-CNPDA, 1991. cap.11, p.181-193.

REUNIÃO BRASILEIRA SOBRE ALTERNATIVAS AO BROMETO DE METILA, 1., Florianópolis, 1997. Palestras. Florianópolis: EPAGRI, 1997. 334p.

RODRÍGUEZ-KÁBANA, R. ; CALVET, C. Capacidad del suelo para controlar enfermidades de origen edafico. Fitopatologia Brasileira, v.19, n.2, p.129-138, 1994.

SCHUELER, C.; BIALA, J.; VOGTMANN, H. Antiphytopathogenic properties of biogenic waste compost. Agriculture, Ecosystems and Environment, v.27, p.477$482,1989$.

SILVA, T.M.W; TOLEDO, A.C.D.; CARDOSO, R.M.G.; MILANEZ, A.I. Pythium mamillatum e $P$. rostratum associados à podridão de raizes de crisântemo (Chrysantemum sp.) em São Paulo, SP. Summa Phytopathologica, v.15, n.3-4, p.215-221, 1989.

STAPLETON, J.J.; DEVAY, J.E. Soil solarization: a natural mechanism of integrated pest management. In: autores do livro. Novel approaches to integrated pest management. Boca Ranton: Lewis Publi., 1995. p.309-322.

THEODORE, M.; TORIBIO, J.A. Supression of Pyhtium aphanidermatum in composts prepared from sugarcane factory residues. Plant and Soil, v.177, p.219-223, 1995. 
TUITERT, G.; SZCZECH, M.; BOLLEN, G.J. Suppression of Rhizoctonia solani in potting mixtures amended with compost made from organic household waste. Phytopathology, v.88, n.8, p.764-773, 1998.

VIDA, J.B.; KUROSAWA, C.; ESTRADA, K.R.F.S.; SANTOS, H.S. Manejo fitossanitário em cultivo protegido. In: GOTO, R.; TIVELLI, S.W. Produção de hortaliças em ambiente protegido: condições subtropicais. São Paulo: UNESP, 1998. cap.3, p.53-104.

WALKER, J.C.; MORELL, S.; FOSTER, H.H. Toxicity of mustard oils and related sulfur compounds to certain fungi. American Journal of Botany, v.24, p.536-541, 1937. 